\title{
QUALITY OF HERBAL MEDICINAL PRODUCTS BASED ON SAGE AND THYME PREPARATIONS
}

\author{
AGNIESZKA BODALSKA*, ADAM KOWALCZYK, and IZABELA FECKA
}

\author{
Department of Pharmacognosy and Herbal Medicines, Faculty of Pharmacy, \\ Wroclaw Medical University, ul. Borowska 211, 50-556 Wroclaw, Poland
}

\begin{abstract}
Sage and thyme are herbs that have been traditionally used in various forms for upper respiratory tract infections and inflammation of mucous membranes. The activity of these medicinal plants was mainly attributed to the essential oil. Its lowest content in herbal substances approved for pharmaceutical use is defined by the respective monographs of the European Pharmacopoeia or national pharmacopeias. Studies carried out in recent years emphasize also the importance of non-volatile compounds present in these plants - polyphenols, which also have a versatile beneficial therapeutic potential for health. Our study included a qualitative analysis of polyphenols in commercial herbal medicines based on sage and thyme and quantification of levels of the most important non-volatile components using the $U(H)$ PLC-ESI-MS and HPLC-DAD methods along with the analysis of variance (ANOVA). This research highlighted the great diversity of the most abundant compounds - rosmarinic acid and luteolin-7-O- $\beta$ glucuronide. Since polyphenols are present in the tested herbal medicines in considerable amounts, their concentration and participation in the therapeutic effect should not be ignored. Therefore, the content of rosmarinic acid and luteolin-7-O- $\beta$-glucuronide in sage leaf and thyme herb is proposed as another parameter for quality control purposes.
\end{abstract}

Keywords: flavonoids, phenolic acids, Salvia officinalis, Thymus vulgaris, herbal medicinal product, Thymus zygis

Herbal preparations have a diverse character, from simple shredded plant material, e.g. herbal teas, to complex products manufactured by the pharmaceutical industry. Many of them are available in pharmacies as over-the-counter (OTC) products or in stores. An important factor determining their quality and, consequently, the therapeutic effect is the constant and reproducible composition of the active substance(s). Herbal medicinal product (HMP) is defined as any medicinal product exclusively containing as active ingredient at least one herbal substance or one herbal preparation. The quality of selected herbal substances and herbal preparations is defined by the national pharmacopeias, and within the European Union also by the European Pharmacopoeia (Ph. Eur.). Starting materials, intermediates, and finished herbal medicinal products are evaluated according to procedures specified in manufacturer specifications; based on pharmacopoeial monographs, guidelines of medicines regulatory authorities and organizations, GLP (Good Laboratory Practice), and GMP (Good Manufacturing Practice) principles (1). In contrast to medicinal products with a single active substance, HMPs include a complex matrix of bioactive components, which causes significant difficulty in maintaining their reproducible quality and efficacy. Sage leaf and thyme herb, as well as their preparations such as a tincture or hydroalcoholic extracts (e.g. Salviae tincura, Thymi extractum fluidum) are mainly evaluated for the essential oil content, sometimes also for their individual components (e.g. thymol and carvacrol). Although the polyphenolic compounds, for example, caffeic acid esters, are considered to be a quality indicator in other pharmacopoeial substances from the Lamiaceae family (Ballotae nigrae herba, Lycopi herba, Melissae folium, Melissae folii extractum siccum, Menthae piperitae folii extractum siccum, Rosmarini folium, Salviae miltiorirrhizae radix et rhizoma), their concentration is not controlled for sage and thyme (2). The lack of guidelines for the minimum level of these constituents may cause differences in the quality of sage and thyme-based HMPs even between consecutive batches of the same product, which could have a negative impact on the expected therapeutic effect.

\footnotetext{
* Corresponding author: e-mail: agnieszka.bodalska@student.umed.wroc.pl
} 
Sage and thyme are among the best-known aromatic plants in the Lamiaceae family. Due to the content of essential oils with known antiseptic and antiphlogistic properties, these plants are used topically in infectious diseases, e.g., to treat inflammation of the mouth and throat. Besides, thyme preparations are used orally as expectorants and antispasmodic (bronchospasmolytic) agents in acute and chronic bronchitis with productive cough. A comprehensive monograph on the pharmacological properties of sage was provided by Ghorbani and Esmaeilizadeh (3), and thyme by Prasanth (4).

Salvia officinalis L. was widely used as a medicine since ancient Egypt and Europe, mainly in laryngitis, bronchitis, and tonsillitis (5). Sage leaf (Salviae officinalis folium) and sage tincture (Salviae tincturae) are included in the $\mathrm{Ph}$. Eur. and are classified by HMPC/EMA (The Committee for Herbal Medicinal Products of the European Medicines Agency) as traditional herbal medicines for use in specified indications based upon long-standing use (2). Those indications include cases of mild dyspeptic disorders such as heartburn and bloating, excessive sweating, irritations of mouth, throat, or skin (6, 7). Salviae officinalis folium is defined by $\mathrm{Ph}$. Eur. as a whole or cut, dried leaf with a minimum essential oil content of $10 \mathrm{~mL} / \mathrm{kg}$ for the cut and $12 \mathrm{~mL} / \mathrm{kg}$ for the whole plant material. Pharmacopoeial sage tincture is produced by extracting 1 part of the sage leaf with 10 parts of $70 \%$ ethanol (V/V). This tincture is also standardized for essential oil content, which should not be less than $0.1 \%(\mathrm{~m} / \mathrm{m})(2)$. Sage leaf medicinal products currently available in the pharmacy market are the comminuted herbal substance for oral, oromucosal, or cutaneous use, solid or liquid herbal medicines for oral use, and liquid or semi-solid products for topical use. The main groups of sage components are phenolic acids (caffeic acid esters or caffeetannins; about 3.5\%), followed by essential oil (up to $3 \%$ ) and flavonoids (1.1\%). Phenolic diterpenes should also be mentioned, among which the concentration of the major representative, carnosol, is up to $0.35 \%$ (8). Interest in S. officinalis, as a natural free radical scavenger, has led to the isolation and identification of many from its phenolic components with potent antioxidant activity in vitro (9). A comprehensive review of polyphenols in various sage species was carried out by Lu and Foo (10). Along with the research on the chemical composition of sage leaf, research into the potential use of its aqueous and hydroethanolic extracts was conducted. These studies demonstrated antibacterial, antiviral, antifungal, and insecticidal action, as well as a beneficial effect on wound healing (11-13). The results of Nogueira de Melo et al. (14) further showed that the hydroalcoholic extract of sage has topical antiedematous effects similar to dexamethasone. The authors indicated polyphenols, in particular rosmarinic acid and flavonoids, as responsible for this action. According to Mocan et al. (15), S. officinalis showed higher total phenolic content and stronger antibacterial, antifungal activity than the other sage species analyzed in the study.

The well-studied chemical composition of S. officinalis has become the basis for some restrictions on its use. Sage toxicity data mainly relate to the essential oil that contains thujone (mostly $(+)$ - $\alpha$-thujone), which has neurotoxic potential (acts as a competitive antagonist of GABA) (16). In several cases, the use of sage essential oil has been associated with the occurrence of convulsions or epileptic seizures (8). Therefore, HMPC/EMA-compliant sage medicinal products must have a specification showing that the daily amount of thujone does not exceed the set limit $(6 \mathrm{mg})$ at the approved dosage. The thujone content must be shown for each product batch (8).

Thyme herb is widely used as a herbal medicine with antiseptic, antispasmodic, carminative, and antitussive properties $(4,17)$. A thorough summary of the chemical composition of the plants from the Thymus genus and an overview of their biological properties has been prepared by Li and co-workers (18). The Ph. Eur. defines thyme herb (Thymi her$b a$ ), as a mixture of previously dried whole leaves and flowers separated from stems of Thymus vulgaris L. and Thymus zygis L. with the minimum content of essential oil at $12 \mathrm{~mL} / \mathrm{kg}$ of dried herbal substance. The essential oil should contain at least $40 \%$ of thymol and carvacrol (2). There are 6 chemotypes of thyme, which differ in essential oil composition. Only one of them is listed in the Ph. Eur. - Thymi typo thymolo aetheroleum, with thymol as a predominant compound. The report published by the HMPC/EMA includes the use of thyme preparations as an expectorant in cough associated with cold (19). The indications are based only upon longstanding use. The Polish Pharmacopoeia also provides a monograph of thyme syrup (Thymi sirupus compositus) prepared by mixing Thymi extractum fluidum with 10\% ammonia, ethanol 90\% (V/V), thymol and simple syrup. The content of thymol in this preparation should range from $0.012 \%(\mathrm{~m} / \mathrm{m})$ to $0.016 \%(\mathrm{~m} / \mathrm{m})$. Besides essential oil, T. vulgaris and T. zygis contain also many other constituents, e.g., flavonoids such as glycosides of flavones (luteolin, apigenin), methylated flavones, and flavanones. According to research, the luteolin content reaches 


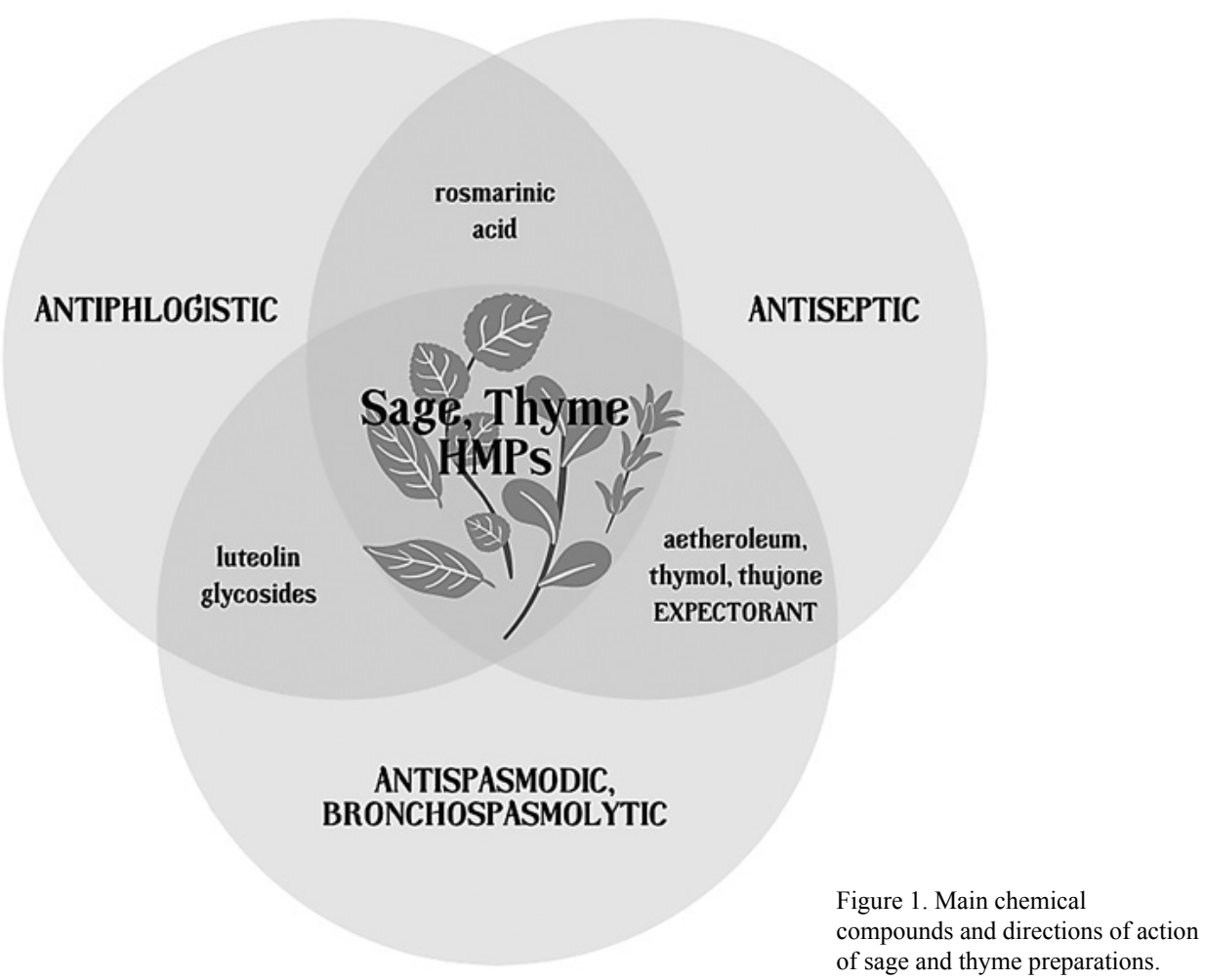

$1.19 \mathrm{mg} / \mathrm{g}$ of dried herbal substance (20). Another significant group of thyme bioactive compounds comprises phenolic acids, such as rosmarinic acid. The free radical scavenging activity of $T$. vulgaris preparations is correlated with the content of phenolic acids $(21,22)$. Some new studies have demonstrated the antiviral, antibiofilm, antifungal, antileishmanial, and antineoplastic properties of thyme herb (23). Shaban and co-workers (24) proved that topical application of ointment with thyme hydroethanolic extract to wounds significantly accelerate their healing. This study also revealed that thyme extract has dose-dependent antiulcerogenic effects. Generally, thyme herb preparations are considered safe, and therefore, they can be given to children from 4 years of age (21).

The medicinal properties of sage and thyme have so far been attributed mainly to the essential oil content. Nevertheless, other pharmacologically active components, such as polyphenols, were also detected in large quantities in their aqueous and hydroethanolic extracts. A summary of the main active ingredients of sage and thyme attributed to their therapeutic effects is shown in Figure 1. Based on the above data on the chemical composition of sage leaf and thyme herb, we decided to assess the quality of selected HMPs containing their preparations in terms of polyphenols (including phenolic acids and flavonoids). The manufacturers of these medicinal products did not standardize them for either phenolic acid or flavonoid content. Thus, our study aimed to compare the polyphenolic composition of sage and thyme-based HMPs, as well as to determine the concentration of key non-volatile components. For this purpose, the content of phenolic acids, flavonoids, and polyphenols in different batches of six sage and thyme commercial herbal medicines was analyzed. A group of liquid HMPs containing extracts of sage and thyme with a similar therapeutic profile (infectious and inflammatory diseases of the upper respiratory tract and oral cavity) from different producers and with different lot numbers was selected. In this work, we provide a new, broader perspective on the pharmaceutical analysis and standardization of sage and thyme preparations. We have shown that to ensure reproducible quality of sage and thyme medicinal products, it is necessary to monitor not only the essential oil content but also the concentration of the two main non-volatile components - rosmarinic acid and luteolin-7- $O-\beta$-glucuronide.

\section{EXPERIMENTAL}

\section{Solvents and chemicals}

All used reagents were of analytical grade. U(H)PLC-ESI-MS grade chemicals: water and formic acid were purchased from Merck (Darmstadt, Germany), acetonitrile was purchased from 
Honeywell (Morris Plains, NJ, USA), whereas methanol and ethanol were purchased from POCh (Lublin, Poland). HPLC gradient grade chemicals: acetonitrile, methanol, and 90-100\% formic acid were purchased from Sigma-Aldrich (St. Louis, MO, USA). Water used in HPLC analysis was obtained with Hydrolab Deionizer HLP20UV in the process of distillation and deionization.

\section{Reference compounds and standard solutions}

Fourteen standard solutions of polyphenols (flavonoids and phenolic acids) and phenolic diterpenes were used in chromatographic analysis. Eight commercial standards - apigenin-7-O- $\beta$ glucoside, eriodictyol (E), luteolin (L), luteolin-7$O$ - $\beta$-glucoside $(\mathrm{Lg})$, naringenin, rosmarinic acid (RA), salvianolic acid B (SAB), and carnosol - were purchased from Extrasynthese (Genay, France); chlorogenic acid (ChA) was purchased from Carl Roth (Karlsruhe, Germany); caffeic acid (CA) was purchased from Koch-Light Laboratories (Haverhill, UK). Four standards were isolated with 97\% purity (HPLC-DAD) from plant material: eriocitrin - eriodictyol-7-O-rutinoside (Er) and luteolin-7-Orutinoside $(\mathrm{Lr})$ from Mentha $\times$ piperita L. leaves, luteolin-7-O- $\beta$-glucuronide (Lgr), and lithospermic acid A from Thymus serpyllum L. herb [54]. A weighted amount of standard (about 1.0-1.7 mg/ $\mathrm{mL}$ ) was dissolved in an appropriate amount of methanol. Obtained stock standard solution $(1.0 \mathrm{mg} /$ $\mathrm{mL}$ ) was diluted with $50 \%$ aqueous methanol (V/V) in order to obtain working standard solutions with concentrations of $0.02,0.05,0.10,0.15,0.20$ and $0.30 \mathrm{mg} / \mathrm{mL}$. Working standard solutions were filtered through hydrophilic Millex syringe filters (Durapore $0.22 \mu \mathrm{m}$; Millipore, Burlington, MA, USA) and stored at $-20^{\circ} \mathrm{C}$.

\section{Plant material and sample preparation}

38 liquid herbal medicinal products containing 6 types of preparations from $S$. officinalis and T. vulgaris or T. zygis were purchased from local pharmacies in the years 2017-2020. The products were within their shelf life, showed different lot numbers, and were from domestic pharmaceutical manufacturers: Hasco-Lek (Wroclaw, Poland), Herbapol (Lublin, Poland), Herbapol (Kraków, Poland), Phytopharm (Klęka, Poland), and Polpharma (Starogard Gdański, Poland). Four of those medicines were for external use (preparation for external use, PEX) and two for internal ( $p$ reparation for internal use, PIN). PIN2 (THYME SIRUP) was diluted with water in a $1: 5$ ratio, other samples were diluted with $80 \%$ methanol
(V/V); PEX2 in a $1: 5$ ratio, PIN1, and PEX3 in a $1: 10$ ratio, PEX1 and PEX4 (SAGE TINCTURE) in a $1: 20$ ratio. Solutions were filtered through $0.22 \mu \mathrm{m}$ Durapore filters (Millipore, Burlington, MA, USA) and used in qualitative and quantitative analysis with U(H)PLC-ESI-MS and HPLC-DAD methods. In addition to commercially available medicinal products hydroethanolic extracts from both the dried sage leaf and dried thyme herb (KAWON - HURT Nowak sp.j., Gostyń, Poland; certified Good Manufacturing Practice 2019, HACCP Codex Alimentarius Annex to CAC/RCP 1-169, 2009), were used as herbal reference materials in chromatographic analysis. Samples of herbal reference materials ( $\sim 5 \mathrm{~g})$ were powdered with a mortar and then sieved through a 0.355 sieve. Portions of $0.1 \mathrm{~g}$ of the plant materials were weighed with an accuracy of one-thousandth using the analytical balance and placed in the separate $10 \mathrm{~mL}$ volumetric flasks. For hydroethanolic extracts, $8 \mathrm{~mL}$ of $50 \%$ aqueous ethanol $(\mathrm{V} / \mathrm{V})$ was added to volumetric flasks. The solutions were then placed in an ultrasonic bath (Sonorex Digital 10P; Bandelin Berlin, Germany) at ambient temperature (endpoint $<40^{\circ} \mathrm{C}$ ) for 15 minutes. After that time, the content of the flasks was supplemented with $50 \%$ aqueous ethanol to $10 \mathrm{~mL}$ (yielding DER - the drug-extract ratio of $1: 100$ ), and filtered through filter papers. From the obtained hydroethanolic extracts, dilutions were prepared with $50 \%$ aqueous methanol. Before chromatographic analysis, they were filtered by $0.22 \mu \mathrm{m}$ Durapore filters.

\section{U(H)PLC-ESI-MS conditions}

The qualitative part of the analysis was performed with mass spectrometry coupled with ultra-high performance liquid chromatography. The hardware used in this study was Thermo Scientific U(H)PLC Ultimate 3000 apparatus (Thermo Fisher Scientific, Waltham), a set of LPG-3400RS quaternary pumps with a vacuum degasser, WPS3000TRS autosampler, TCC-3000SD column oven, DAD-3000 photodiode detector, ESI-qTOF Compact HRMS detector (Bruker Daltonics, Bremen, Germany) and a Kinetex RP-18 column $(150 \times 2.1 \mathrm{~mm}$ i.d., octadecyl $2.6 \mu \mathrm{m}$; Phenomenex, Torrance, CA, USA) with dedicated precolumn. The analysis was run in negative mode. Scan range was $50-2200 \mathrm{~m} / \mathrm{z}$, with a low mass set at $200 \mathrm{~m} / \mathrm{z}$. Parameters set for the source were: nebulizer pressure 1.5 bar, flow of the dry gas $\left(\mathrm{N}_{2}\right) 7.0 \mathrm{~L} / \mathrm{min}$, temperature $200^{\circ} \mathrm{C}$, and capillary voltage $2.2 \mathrm{kV}$. The ion energy of the quadrupole was $5 \mathrm{eV}$. In the collision cell, $\mathrm{N}_{2}$ was used as collision gas, collision 
Table 1. Validation parameters of standard compounds for HPLC-DAD analysis.

\begin{tabular}{|c|c|c|c|c|c|c|}
\hline Standard & Calibration Equation & $r^{2}$ & $\begin{array}{c}\text { Linear Range } \\
(\mu \mathrm{g} / \mathrm{mL})\end{array}$ & $\begin{array}{c}\text { LOD } \\
(\mu \mathrm{g} / \mathrm{mL})\end{array}$ & $\begin{array}{c}\text { LOQ } \\
(\mu \mathrm{g} / \mathrm{mL})\end{array}$ & $\begin{array}{c}\text { Working } \\
\text { Wavelength } \\
(\mathrm{nm})\end{array}$ \\
\hline \multicolumn{7}{|c|}{ Flavones } \\
\hline Luteolin & $\mathrm{y}=1224.6 \mathrm{x}-0.1205$ & 0.9990 & $10-300$ & 0.24 & 0.82 & 360 \\
\hline Luteolin-7- $O-\beta$-glucuronide & $\mathrm{y}=615.69 \mathrm{x}-0.9761$ & 0.9996 & $10-250$ & 0.49 & 1.62 & 360 \\
\hline Luteolin-7- $O$-rutinoside & $\mathrm{y}=457.74 \mathrm{x}-0.9438$ & 0.9998 & $10-250$ & 0.65 & 2.18 & 360 \\
\hline \multicolumn{7}{|c|}{ Flavanones } \\
\hline Eriodictyol & $\mathrm{y}=330.28 \mathrm{x}+0.2099$ & 0.9998 & $10-250$ & 0.91 & 3.03 & 280 \\
\hline Eriocitrin & $\mathrm{y}=239.18 \mathrm{x}+0.8709$ & 0.9992 & $10-300$ & 1.25 & 4.19 & 280 \\
\hline \multicolumn{7}{|c|}{ Phenolic acids-Caffeetannins } \\
\hline Caffeic acid & $\mathrm{y}=1824.74 \mathrm{x}-4.64$ & 0.9993 & $10-300$ & 0.16 & 0.55 & 320 \\
\hline Chlorogenic acid & $\mathrm{y}=926,35-7.24$ & 0.9992 & $10-300$ & 0.32 & 1.08 & 320 \\
\hline Rosmarinic acid & $\mathrm{y}=581.91 \mathrm{x}+1.99$ & 0.9991 & $10-300$ & 0.51 & 1.72 & 320 \\
\hline
\end{tabular}

$r^{2}$, coefficients of determination; LOD, limit of detection; LOQ, limit of quantitation; $\mathrm{n}=2 \times 5$

energy was at $10 \mathrm{eV}$ in basic MS mode, and auto MS/MS mode was used for ions in the range $400-$ $1900 \mathrm{~m} / \mathrm{z}$. The concentration of eluents $-0.1 \%$ formic acid in water (A) and $0.1 \%$ formic acid in acetonitrile (B) - followed the scheme: $0-1 \min (2 \% \mathrm{~B}$ in A), $1-31 \mathrm{~min}(2 \rightarrow 100 \% \mathrm{~B}$ in A), $31-36 \mathrm{~min}(100 \%$ $\mathrm{B}$ in $\mathrm{A})$. The injection volume was $5 \mu \mathrm{L}$. In order to avoid contamination, blanks were run after each sample. Obtained data were analyzed using Data Analysis 4.2 Software (Bruker Daltonics).

\section{HPLC-DAD conditions}

In HPLC-DAD analysis a Dionex Thermo Scientific Ultimate 3000 high-performance liquid chromatograph equipped with an LPG-3400D pump, WPS-3000TSL autosampler, column thermostat, and diode array detector DAD-3000 were used. The separation was performed on a Thermo Hypersil Column (250 mm × 4.6 i.d., octadecyl Beta Basic-18 $\varnothing 5 \mu \mathrm{m}$, Loughborough, UK). Spectral measurements of UV-Vis were made in the wavelength range 200-600 nm, in steps of $2 \mathrm{~nm}$. Obtained data were processed by Chromeleon Software. Three different wavelengths were used: $280 \mathrm{~nm}$ for flavone derivatives, $320 \mathrm{~nm}$ for caffeic acid derivatives, and $360 \mathrm{~nm}$ for flavone derivatives. As eluents, a mixture of 5\% formic acid in water (eluent C) and 5\% formic acid in acetonitrile (eluent D) was used. The following elution program was used: HPLC gradient: $0-25 \mathrm{~min}(7 \rightarrow 30 \% \mathrm{D}$ in $\mathrm{C}), 25-30 \mathrm{~min}$ $(30 \rightarrow 70 \% \mathrm{D}$ in $\mathrm{C}), 30-35 \mathrm{~min}(70 \rightarrow 7 \% \mathrm{D}$ in $\mathrm{C})$. Other analysis conditions were $20^{\circ} \mathrm{C}$, sample injection of $20 \mu \mathrm{L}$, the eluent flow rate at $0.9 \mathrm{~mL} / \mathrm{min}$. This method was developed and validated by Fecka and Turek (20).

\section{Calibration and content measurement}

Calibration was made for eight reference compounds: luteolin, luteolin-7- $O$ - $\beta$-glucuronide, luteolin-7-O-rutinoside, eriodictyol, eriocitrin, caffeic acid, chlorogenic acid, and rosmarinic acid. Calibration equations were designated from 5 concentration levels, and duplicate injections were performed for each sample. Linearity tests were conducted for two different sample weights, on two different days. Standard curves were plotted for peak areas (mAU/s) and corresponding concentrations $(\mathrm{mg} / \mathrm{mL})$. Based on the signal-to-noise ratio ( $\mathrm{S} / \mathrm{N} \geq 3: 1$ and $\mathrm{S} / \mathrm{N} \geq 10: 1$ ), limits of detection (LOD) and quantitation (LOQ) were calculated for each analyte $(\mu \mathrm{g} / \mathrm{mL})(25)$. Calibration equations, coefficients of determination $\left(r^{2}\right)$, linear ranges, LOD and LOQ are presented in Table 1. Quantification was performed using HPLC chromatograms recorded at selected wavelengths: $280 \mathrm{~nm}$ - flavanones, $320 \mathrm{~nm}$ - caffeic acid derivatives, $360 \mathrm{~nm}$ - flavones. The sum of flavonoids (SF), caffeic acid derivatives (SCA), and polyphenols ( $\mathrm{SPP}=\mathrm{SF}+\mathrm{SCA})$ was calculated by adding the contents designated for each compound in the respective chemical group. Mean content (mg per $1 \mathrm{~mL}$ of product) and coefficient of variation $(\% \mathrm{CV})$ for all quantified compounds was designated from three independent samples in duplicate.

\section{Statistical analysis}

To determine the significance of intra-batch differences in concentration of two major polyphenols (rosmarinic acid and luteolin-7- $O$ - $\beta$-glucuronide), the 1-factor ANOVA with the post-hoc Scheffé test $(p<0.05)$ was performed for each herbal medicinal 
Table 2. General composition of analyzed liquid herbal medicinal products (HMPs).

\begin{tabular}{|c|c|c|c|}
\hline \multicolumn{2}{|c|}{$\begin{array}{l}\text { Acronym of the Herbal } \\
\text { Medicinal Product, FORM }\end{array}$} & Compounds & Indications \\
\hline \multicolumn{4}{|c|}{ Preparations for external use } \\
\hline PEX1 & LIQUID & $\begin{array}{c}\text { Thyme herb liquid extract (T. vulgaris L. or T. zygis L.), } \\
\text { Sage leaf tincture (S. officinalis L.) }\end{array}$ & $\begin{array}{l}\text { Inflammation of the mouth } \\
\text { and throat }\end{array}$ \\
\hline PEX2 & LIQUID & $\begin{array}{c}\text { Essential oils: clove (Syzygium aromaticum L.), } \\
\text { peppermint leaf (Mentha x piperita L.), thyme herb } \\
\text { (T. vulgaris L. or T. zygis L.), marjoram herb (Origanum } \\
\text { majorana L.); } \\
\text { Liquid extracts: chamomile flower (Matricaria } \\
\text { recutita L.), sage leaf }(\text { S. officinalis L.), yarrow herb } \\
\text { (Achillea millefolium L.), peppermint leaf (Mentha x } \\
\text { piperita L.), thyme herb (T. vulgaris L. or T. zygis L.), } \\
\text { fennel fruit (Foeniculum vulgare Mill.) }\end{array}$ & $\begin{array}{l}\text { Inflammation of the mouth } \\
\text { and throat }\end{array}$ \\
\hline PEX3 & LIQUID & $\begin{array}{l}\text { Liquid extracts: chamomile flower (Matricaria } \\
\text { recutita L.), oak bark (Quercus spp.), sage leaf } \\
\text { (S. officinalis L.), arnica herb (Arnica spp.), calamus } \\
\text { rhizome (Acorus calamus L.), peppermint leaf } \\
\text { (M. piperita L.), thyme herb (T. vulgaris L. or T. zygis L.) }\end{array}$ & $\begin{array}{l}\text { Inflammation of the mouth } \\
\text { and gums, aphthae, sores in } \\
\text { the oral cavity }\end{array}$ \\
\hline PEX4 & \begin{tabular}{c|} 
SAGE \\
TINCTURE
\end{tabular} & Sage leaf tincture (S. officinalis L.) & $\begin{array}{l}\text { Inflammation of the mouth, } \\
\text { gums and throat }\end{array}$ \\
\hline \multicolumn{4}{|c|}{ Preparations for internal use } \\
\hline PIN1 & LIQUID & $\begin{array}{c}\text { Liquid extracts: thyme herb (T. vulgaris L. or T. zygis L.), } \\
\text { Icelandic moss (Cetraria islandica (L.) Ach.), hyssop } \\
\text { herb (Hyssopus officinalis L.), soapwort root (Saponaria } \\
\text { officinalis L.) }\end{array}$ & $\begin{array}{l}\text { Inflammation of the } \\
\text { respiratory tract, difficult } \\
\text { expectoration with retained } \\
\text { secretion }\end{array}$ \\
\hline PIN2 & $\begin{array}{l}\text { THYME } \\
\text { SYRUP }\end{array}$ & Thyme herb liquid extract (T. vulgaris L. or T. zygis L.) & $\begin{array}{l}\text { Cough with upper } \\
\text { respiratory tract rhinitis, } \\
\text { difficult expectoration }\end{array}$ \\
\hline
\end{tabular}

product. The Shapiro-Wilk test was used to check the normality of data distribution, and Brown-Forsythe's test was used to assess the equality of group variances. All calculations were performed with Statistica 13 software.

\section{RESULTS}

\section{Identification of polyphenols and other non-volatile components}

The compounds of examined herbal medicines are presented in Table 2 . We initially compared the chemical composition of the tested herbal medicinal products (liquids, tinctures, syrups) with hydroethanolic extracts of sage and thyme (herbal reference materials) by chromatographic methods. Fourteen authentic standards were used in chromatographic analyses. A summary of significant peaks observed in the experiment performed using ultrahigh-performance liquid chromatography coupled to an electrospray ionization mass spectrometry $(\mathrm{U}(\mathrm{H})$ PLC-ESI-MS) is shown in Tables 3 and 4. The U(H) PLC-ESI-MS analysis of sage and thyme hydroethanolic extracts (Drug Extract Ratio - DER 1:100) and commercial HMPs led to the identification of the following numbers of compounds: 65 in $S$. officinalis preparations and 57 in T. vulgaris / T. zygis preparations. Chemical structures of identified salvianolic acids and other polyphenols are shown in Figures 2-3. The flavone and flavanone structures were presented in our previous paper (26).

\section{Sage leaf preparations}

The U(H)PLC-ESI-MS analysis on sage hydroethanolic extract and sage tincture (PEX4) resulted in the discovery of 7 caffeic acids derivatives $(1,12$, $24,29,30,31,44)$. The identity of peak 31 , rosmarinic acid, which eluted at $12.86 \mathrm{~min}$., was confirmed by comparing its retention time, UV-Vis, and MS spectra to the authentic standard. Two peaks, tentatively identified as glycosides: 6-O-caffeoyl-fructosylglucoside (peak $1, \mathrm{~m} / \mathrm{z}$ at 503) and $\beta$-glucoside of 2,3,4-trihydroxy-3-methylbutyl, 6-[-3-(4-hydroxy3-methoxyphenyl)-2-propenoate (peak 12, $\mathrm{m} / \mathrm{z}$ at 473), were previously assigned in $S$. officinalis by Wang and co-workers $(27,28)$. The presence of sagerinic acid and two salvianolic acids $\mathrm{A}$ and $\mathrm{K}$, previously reported by researchers, was confirmed in 


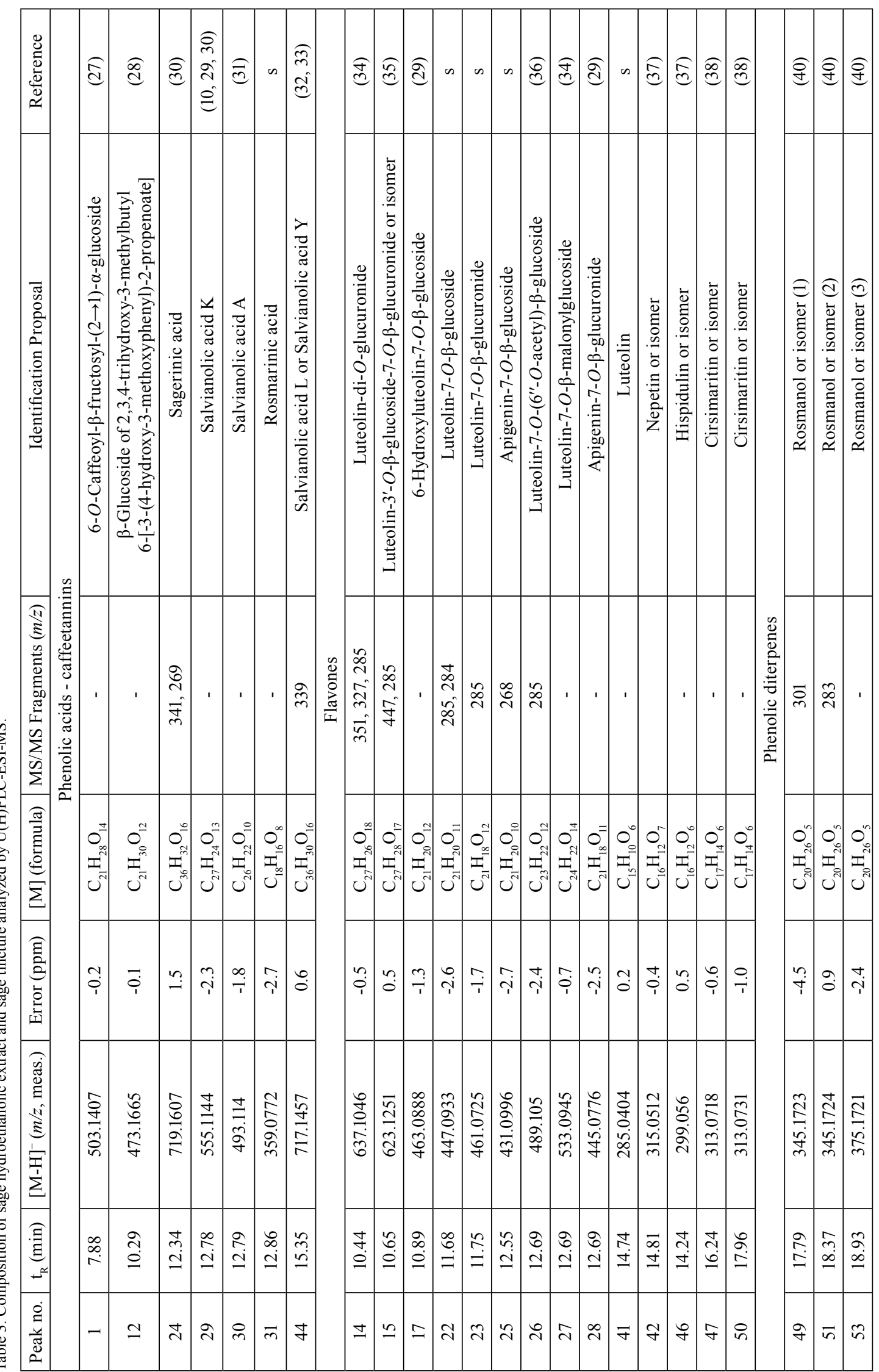




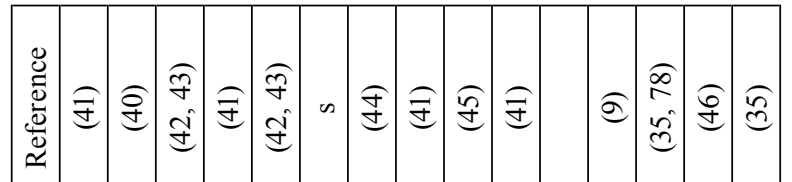

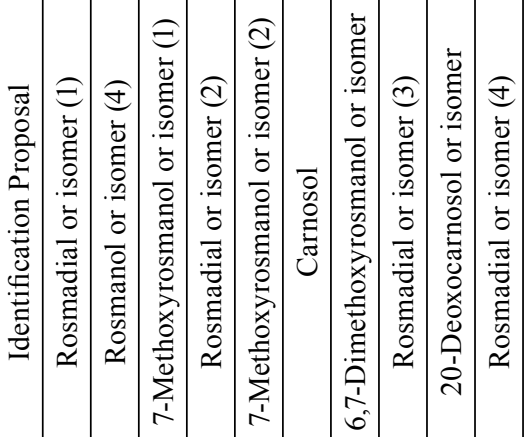

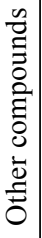
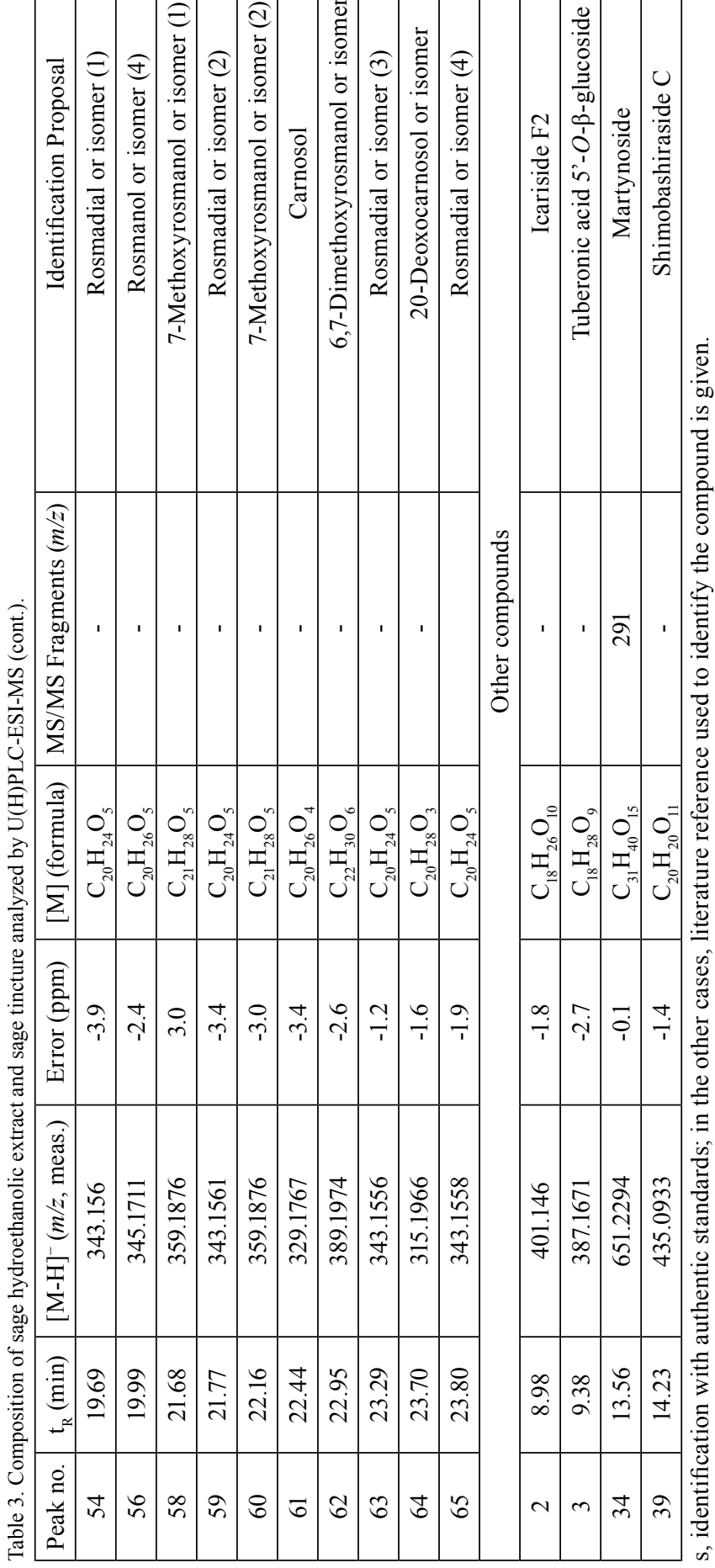

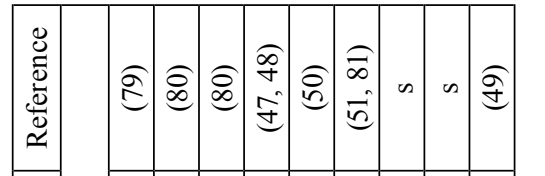

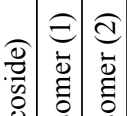

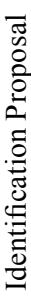

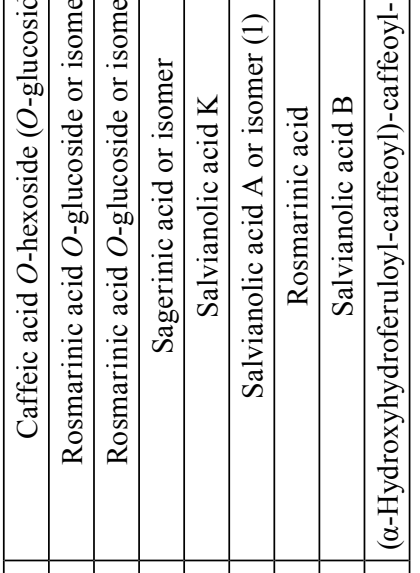

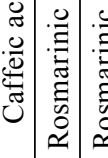

$\stackrel{\infty}{\sim}$

ลิ

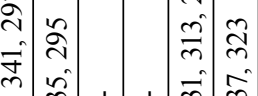

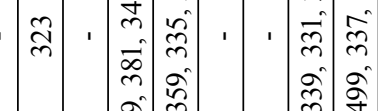

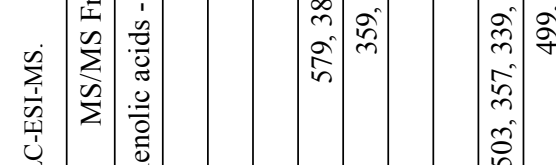

굴

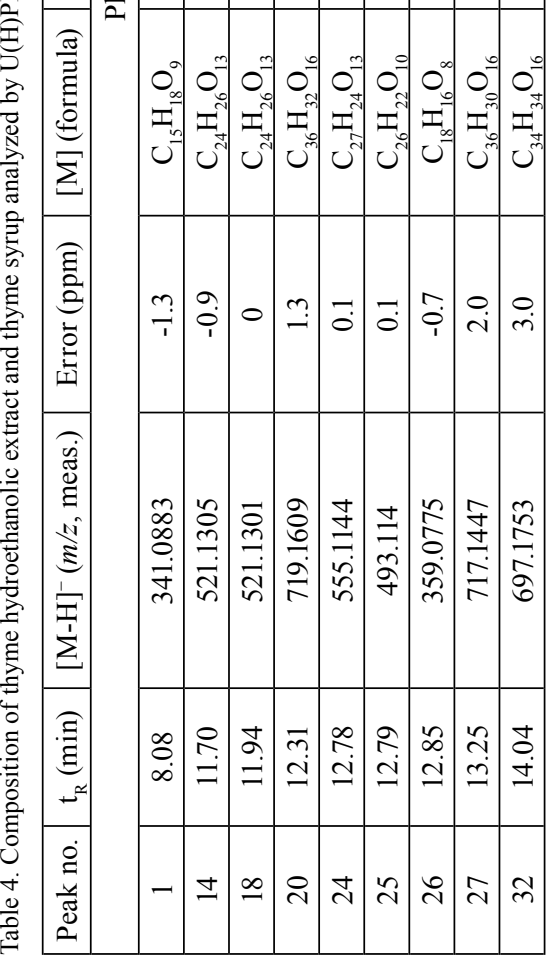




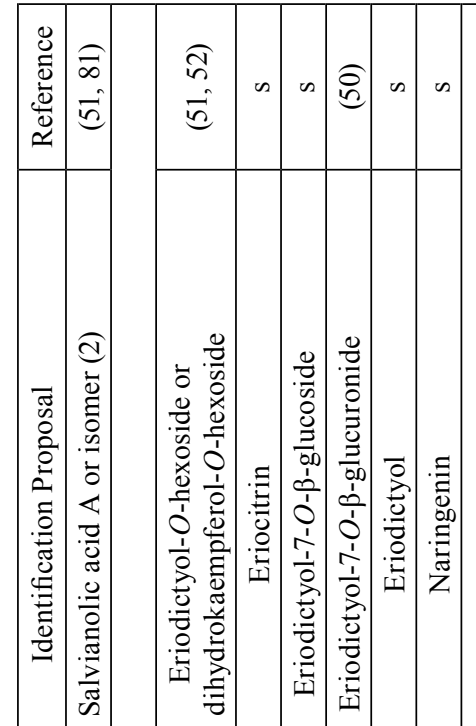

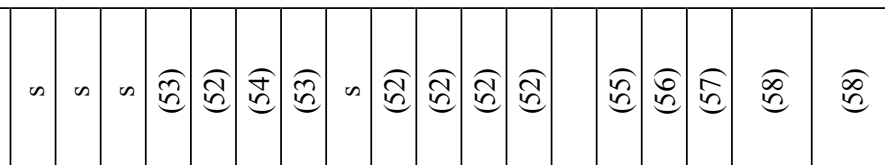
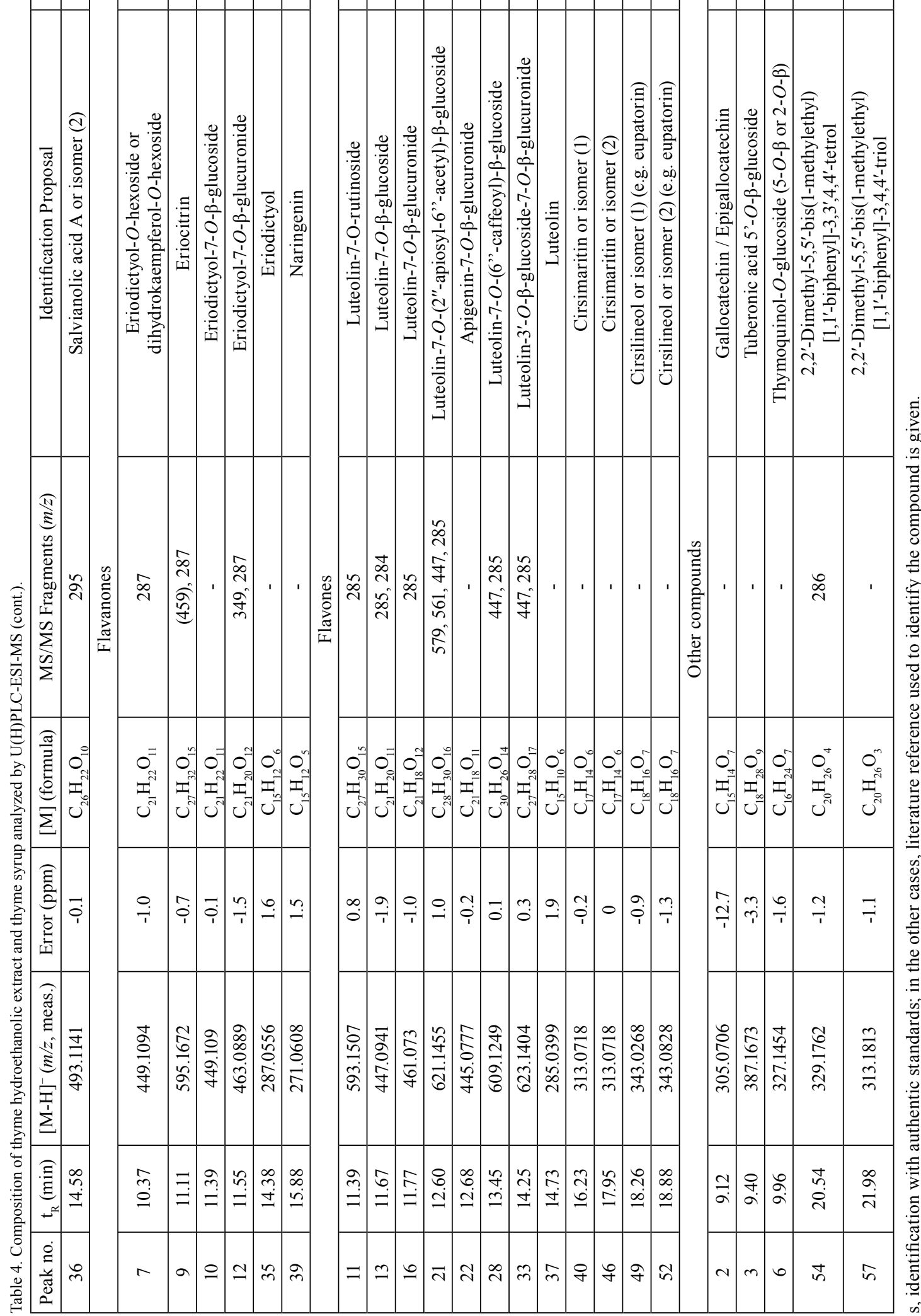

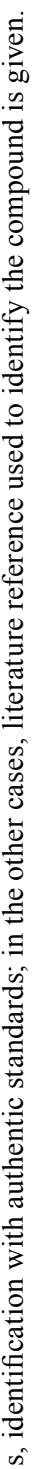


<smiles>O=C(/C=C/c1ccc(O)c(O)c1/C=C/c1ccccc1)OC(Cc1ccc(O)c(O)c1)C(=O)O</smiles>

Salvianolic acid A<smiles>O=C(OC(Cc1ccc(O)c(O)c1)C(=O)O)C1=Cc2ccc(O)c(O)c2C(C(=O)OC(Cc2ccc(O)c(O)c2)C(=O)O)C1c1ccc(O)c(O)c1</smiles>

Salvianolic acid L<smiles>CC(Cc1ccc(O)c(O)c1)C(=O)OC(=O)C1C(C(=O)OC(Cc2ccc(O)c(O)c2)C(=O)O)[C@H](c2ccc(O)c(O)c2)C1c1ccc(O)c(O)c1</smiles>

Sagerinic acid<smiles>O=C(/C=C/c1ccc(O)c2c1[C@H](C(=O)OC(Cc1ccc(O)c(O)c1)C(=O)O)C(c1ccc(O)c(O)c1)O2)OC(Cc1ccc(O)c(O)c1)C(=O)O</smiles>

Salvianolic acid $B\left({ }^{*}=R\right) /$ Salvianolic acid $Y\left({ }^{*}=S\right)$<smiles>O=C(/C=C/c1ccc(O[C@H](C(=O)O)[C@@H](O)c2ccc(O)c(O)c2)c(O)c1)OC(Cc1ccc(O)c(O)c1)C(=O)O</smiles><smiles>COc1cc(CC(OC(=O)/C=C\c2ccc(O)c(O)c2)C(=O)OC2OC(COC(=O)/C=C/c3ccc(O)c(O)c3)C(O)C(O)C2O)ccc1O</smiles>

a-Hydroxyhydroferuloyl-caffeoyl)-caffeolyl-O-hexoside
Figure 2. Structures of phenolic acids - caffeetannins.<smiles>O=C(/C=C/c1ccc(O)c(O)c1)OC(Cc1ccc(O)c(O)c1)C(=O)O</smiles>

Rosmarinic acid this study (29-31). Peak 44 was tentatively assigned as salvianolic acid $\mathrm{L}$ or salvianolic acid $\mathrm{Y}(32,33)$.

Fourteen peaks were identified as flavone derivatives, and the identity of four of them - luteolin7-O- $\beta$-glucoside (22), luteolin-7- $O$ - $\beta$-glucuronide (23), apigenin-7- $O-\beta$-glucoside (25), and luteolin (41) - was confirmed by comparing their fragmentation behavior, UV-Vis, and retention times to standards. Peaks 17, 27, and 28 with $[\mathrm{M}-\mathrm{H}]^{-}$ions at $\mathrm{m} / \mathrm{z} 463$, 533 , and 445 were suggested as 6-hydroxyluteolin7-O- $\beta$-glucoside, luteolin-7- $O$ - $\beta$-malonylglucoside, and apigenin-7-O- $\beta$-glucuronide based on findings of Dent et al. (29) and Schnitzler et al. (34). The analysis of literature data and fragmentation pattern allowed 
<smiles>O=C(O)C1OC(Oc2cc(O)c3c(=O)cc(-c4ccc(O)c(O)c4)oc3c2)C(O)C(O)C1O</smiles>

Luteolin-7-0- $\beta$-glucuronide

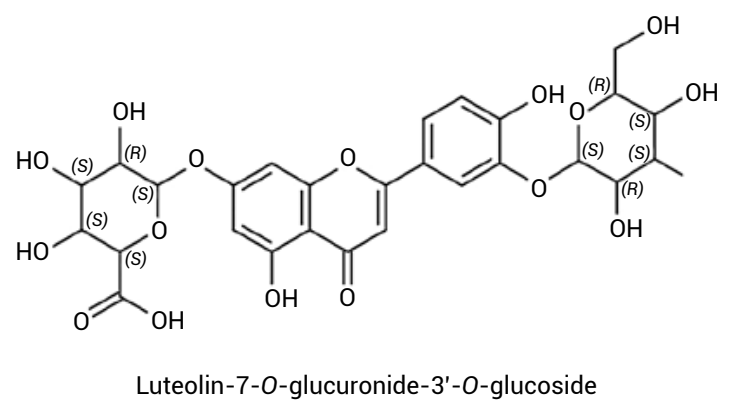

a) Luteolin derivatives<smiles>CC1C(COC(=O)O)OC(Oc2cc(O)c3c(=O)cc(-c4ccc(O)c(O)c4)oc3c2)C(O)[C@@H]1O</smiles>

Luteolin-7-O-(6"-O-acetyl)- $\beta$-glucoside<smiles>CC(=O)OC[C@H]1OC(Oc2cc(O)c3c(=O)cc(-c4ccc(O)c(O)c4)oc3c2)C(OC2OCC(O)(CO)[C@@H]2O)C(O)[C@H]1O</smiles>

Luteolin-7-0-(2"-apiosyl-6"-acetyl)- $\beta$-glucoside

b) Methoxyflavones

Figure 3. Structures of flavonoids: a) Luteolin derivatives, b) Methoxyflavones.

compounds $14(\mathrm{~m} / \mathrm{z}$ 637, MS/MS fragments: 351, 327 and 285) and $15(\mathrm{~m} / z$ 623, MS/MS fragments: $447,285)$ to be tentatively assigned as luteolin-di$O$-glucuronide and luteolin-3'- $O$ - $\beta$-glucoside-7- $O$ $\beta$-glucuronide or its isomer $(34,35)$. Peak 26 with $\mathrm{m} / \mathrm{z} 489$ and an MS/MS fragment at $285 \mathrm{~m} / \mathrm{z}$ could be attributed to luteolin-7- $O$-(6"- $O$-acetyl)- $\beta$-glucoside, a compound previously reported in $S$. fruticosa, but not in S. officinalis (36). Compound $42(\mathrm{~m} / \mathrm{z} 315)$ and two isobaric peaks 47 and $50(\mathrm{~m} / \mathrm{z} 313)$, according to Miura et al. (37) and Nikolova et al. (38), were tentatively identified as nepetin and cirsimaritin isomers. Other assignments are also possible as several researchers report rhamnetin, isorhamnetin, and ladanein presence in S. officinalis extracts (38,
39). Peak 46 was tentatively identified as hispidulin or isomer (37).

Thirteen compounds observed in analyzed samples were assigned as terpenes and their derivatives. The identity of peak 61, carnosol, was confirmed by a comparison of retention time and mass to the authentic standard. Four isobaric peaks (49, 51, 53, and 56) with $\mathrm{m} / \mathrm{z}$ at 345 were tentatively assigned as rosmanol or isomer (e.g. epirosmanol, isorosmanol). MS/MS data showed fragmentation ions at $\mathrm{m} / \mathrm{z} 301$ (peak 49) and 283 (peak 51), which were formed after neutral loss of carbon dioxide (-44 Da) and carbon dioxide with water $(-62 \mathrm{Da})$, as has been described by Kontogianni and co-workers (40). The set of other four isobaric peaks $54,59,63$, and 65 with $\mathrm{m} / \mathrm{z}$ at 
343 was tentatively identified as rosmadial and its isomers. These compounds were previously reported in S. officinalis extracts (41). Peaks 58 and 60, both with $\mathrm{m} / \mathrm{z}$ at 359 could be attributed to the presence of 7-methoxyrosmanol or epirosmanol methyl ether (42, 43). Compounds $62(\mathrm{~m} / \mathrm{z}$ at 389$)$ and $64(\mathrm{~m} / \mathrm{z}$ at 315$)$ were suggested as 6,7-dimethoxycarnosol and 20-deoxocarnosol (or isomers e.g. royleanone, rosmaridiphenol) based on previous literature findings $(44,45)$.

One benzyl alcohol derivative, icariside $\mathrm{F}_{2}$, $m / z$ at 401 , previously reported by Wang (9), was observed in analyzed samples. One representative of phenylpropanoid glycoside $(\mathrm{m} / \mathrm{z}$ at 651$)$, most likely martynoside, was eluted at $13.56 \mathrm{~min}$ (46). The presence of 12-hydroxyjasmonic acid derivative 12-hydroxyjasmonic acid derivatives, tuberonic acid 5'-O- $\beta$-glucoside $(\mathrm{m} / \mathrm{z}$ at 387$)$, and phenolic glycoside - shimobashiraside C, previously detected in S. officinalis extract by Celano and co-workers (35), was also confirmed in this study.

\section{Thyme herb preparations}

The U(H)PLC-ESI-MS analysis on thyme hydroethanolic extract and thyme syrup (PIN2) resulted in the detection of 10 caffeic acids derivatives. Peaks $26(\mathrm{~m} / \mathrm{z}$ at 359$)$ and $27(\mathrm{~m} / \mathrm{z}$ at 717$)$ were identified as rosmarinic acid (RA) and salvianolic acid B (SAB) as their MS, fragmentation patterns, UV-Vis, and retention times were relevant to the authentic standards. Besides SAB, three other salvianolic acids were detected: two salvianolic acid A isomers (peaks 25 and $36, \mathrm{~m} / \mathrm{z}$ at 493 ) and salvianolic acid $\mathrm{K}$. Three phenolic acid glycosides - caffeic acid $O$-glucoside $(\mathrm{m} / \mathrm{z}$ at 341 , $\mathrm{t} R=8.08 \mathrm{~min}$ ) and two rosmarinic acid $O$-glucoside isomers $(\mathrm{m} / \mathrm{z}$ at $521, \mathrm{t} R=11.70 \mathrm{~min}$ and $11.94 \mathrm{~min})$ - were detected in the analyzed samples. Peak 20, $m / z=719$, MS/MS fragments: 579, 381, 341 and 297, was tentatively recognized as sagerinic acid or its isomer. To our knowledge, this compound was identified in other thyme species (T. algeriensis Bioss \& Reut and T. pallescens Noe), but not in T. vulgaris and T. zygis $(47,48)$. Compound 32 with $\mathrm{m} / \mathrm{z}$ at 697 was characterized as ( $\alpha$-hydroxyhydroferuloylcaffeoyl) caffeoyl hexoside. The loss of 2-(4-hydroxy-3-methoxyphenyl) acetaldehyde, $\mathrm{CO}_{2}$ and $\mathrm{H}_{2} \mathrm{O}$ molecules led to the formation of a daughter fragment at $\mathrm{m} / \mathrm{z}$ 323. Other fragments were at $\mathrm{m} / \mathrm{z} 499$ and 337. Such compound has been detected in T. longicaulus by Galasso and co-workers (49).

U(H)PLC-ESI-MS experiment also showed a set of flavanones in both thyme preparations and products. Eriocitrin (peak 9, $\mathrm{m} / z$ 595), eriodictyol-7$O$ - $\beta$-glucoside (peak 10, $\mathrm{m} / \mathrm{z} 449$ ), eriodictyol (peak $35, m / z 287$ ) and naringenin (peak $39, m / z 271$ ) were identified using authentic standards. Peak 12 with $\mathrm{m} / \mathrm{z}$ at 463 , which eluted at $11.55 \mathrm{~min}$, was assigned as eriodictyol-7- $O$-glucuronide based on MS/MS fragments and literature data (50). Peak $7, \mathrm{~m} / \mathrm{z}$ at 449 , was tentatively recognized as eriodictyol- $O$ hexoside; however, according to literature data, other isomers, e.g. dihydrokaempferol (taxifolin) hexoside, are also possible (50-52).

Twelve compounds classified as flavones were detected in the thyme preparations. The identity of peak 11 - luteolin-7- $O$-rutinoside $(\mathrm{m} / \mathrm{z}$ at 593 , MS/MS fragment: $285 \mathrm{Da}), 13$ - luteolin-7-O- $\beta$ glucoside $(\mathrm{m} / \mathrm{z}$ at $447, \mathrm{MS} / \mathrm{MS}$ fragment: 285 and $284 \mathrm{Da}), 16$ - luteolin-7-O- $\beta$-glucuronide $(\mathrm{m} / \mathrm{z}$ at 461, MS/MS fragment: $285 \mathrm{Da})$ and 37 - luteolin $(\mathrm{m} / \mathrm{z}$ at 285$)$ was determined by comparison of retention times, UV-Vis, MS and fragmentation patterns with authentic standards. Neutral loss of the glycone part of peaks 13 and 16 produced a base ion at $m / z 285 \mathrm{Da}$, which refers to luteolin. Similar base peaks at $\mathrm{m} / \mathrm{z} 285$ were observed in the analysis of other luteolin derivatives: peaks 21, 28, and 33. Peak $21(\mathrm{~m} / \mathrm{z}$ at 621$)$ was tentatively identified as luteolin7-O-(2"-apiosyl-acetyl)- $\beta$-glucoside, based on presence of fragment ions at $m / z 579$ [M-H-acetyl] $]^{-}, 561$ [M-H-acetyl- $\left.\mathrm{H}_{2} \mathrm{O}\right], 447$ [M-H-acetyl-apiosyl]-, 285 [M-H-acetyl-apiosyl-glucoside] $]^{-}$. Peak $33(\mathrm{~m} / z$ at $623)$, luteolin-3'-O- $\beta$-glucoside-7- $O-\beta$-glucuronide or isomer, showed fragment ions at $\mathrm{m} / \mathrm{z} 447$ [M-Hglucuronyl] $]^{-}$and 285 [M-H-glucuronyl-glucosyl] $]^{-}$ Those two components were previously reported in T. shimperi R. (53). However, according to our knowledge, they were observed here in thyme herb for the first time. Peak 28 with $\mathrm{m} / \mathrm{z}$ at 609 was assigned as luteolin-7-O-(6"'-caffeoyl)- $\beta$-glucoside as it was observed in some plants of the Thyme genus by Simonyan and co-workers (54). MS/MS fragments refer to neutral loss of the following moieties: 447 [M-H-caffeyl] ${ }^{-}, 285$ [M-H-caffeyl-glucosyl] $]^{-}$. Peak 22 $(\mathrm{m} / \mathrm{z}$ at 445$)$, which eluted at $12.68 \mathrm{~min}$, was assigned as apigenin-7- $O-\beta$-glucuronide and was identical to peak 28 detected in sage preparations (24), (52). Two peaks with $\mathrm{m} / \mathrm{z}$ at 313 and two with $\mathrm{m} / \mathrm{z} 343$ were detected in the analyzed samples and tentatively identified as cirsimaritin or isomer and cirsilineol or isomer.

One catechin derivative, peak 2 , with $\mathrm{m} / \mathrm{z}$ at 305, was assigned as (epi)gallocatechin (55). Compound 3 has been characterized as tuberonic acid 5'-O- $\beta$-glucoside, observed in thyme leaf by Kitajima (56). The mass of pseudo molecular ion $\mathrm{m} / \mathrm{z} 372$ that eluted at $9.96 \mathrm{~min}$ most likely refers to one of thymoquinol glucoside isomers (glucose position $5-O-\beta$ or $2-O-\beta)$, as they were previously detected in thyme herb (57). Two biphenyl derivatives 
- peak $54(\mathrm{~m} / \mathrm{z}$ at 329$)$ and $57(\mathrm{~m} / \mathrm{z}$ at 313$)$ at 20.54 and $21.98 \mathrm{~min}$. - were observed in the analyzed samples. Those compounds were isolated previously from thyme (58).

\section{Content of phenolic acids, flavonoids, and polyphenols in commercial HMPs}

The second part of the study was the quantification of polyphenolic compounds (phenolic acids, flavonoids) in HMPs, which was performed by highperformance liquid chromatography coupled to a diode array detector (HPLC-DAD). Eight polyphenols (RA, CA, ChA, Lgr, L, Lr, Er, E) identified in reference herbal materials were selected for their quality control. We analyzed six different trade herbal medicinal products for internal (PIN1-PIN2) or external (PEX1-PEX4) use, containing sage and thyme preparations. For each of these products, between 3 and 11 batches with different lot numbers were obtained from the same manufacturer. Contents of individual components and the sums of phenolic acids, flavonoids, and polyphenols (by adding the values calculated in each group) were quantified. The intra-batch differences in the content of two major polyphenols - rosmarinic acid and luteolin-7-O- $\beta$ glucuronide - in particular HMPs, were statistically analyzed using one-way ANOVA and post-hoc Scheffé test $(p<0.05)$. Figure 4 presented the content of phenolic acids, flavonoids, and polyphenol sum in the herbal medicines tested.

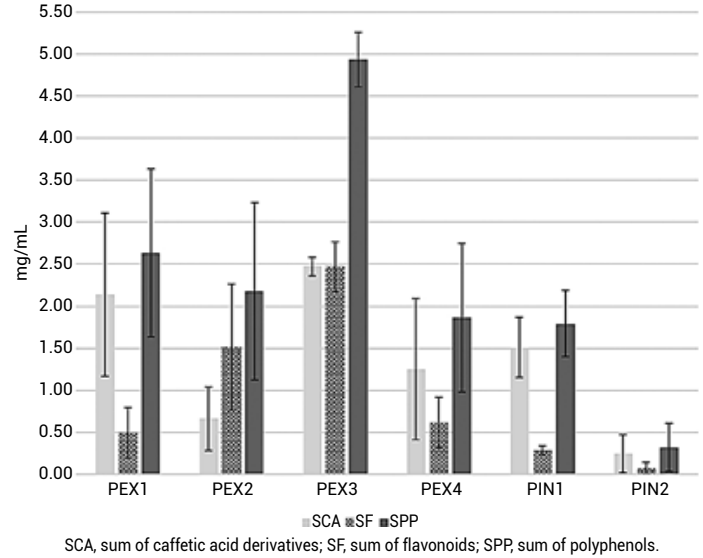

Figure 4. Content $(\mathrm{mg} / \mathrm{mL})$ of phenolic acids, flavonoids and polyphenols in herbal medicines for external (PEX1-4) and internal use (PIN1-2).

\section{Composition of PEX1}

Ten PEX1 (PEX1.1-PEX1.10) batches with different lot numbers were analyzed. Mean concentration of rosmarinic acid was $1.98 \mathrm{mg} / \mathrm{mL}$ (with min. concentration at $0.98 \mathrm{mg} / \mathrm{mL}$ and $\max .4 .00 \mathrm{mg} / \mathrm{mL}$ ), for caffeic acid it was $0.16 \mathrm{mg} / \mathrm{mL}$ ( $\min .0 .10 \mathrm{mg} / \mathrm{mL}$, max. $0.28 \mathrm{mg} / \mathrm{mL}$ ), and for luteolin-7- $O$ - $\beta$-glucuronide $0.50 \mathrm{mg} / \mathrm{mL}$ (min. $0.09 \mathrm{mg} / \mathrm{mL}$, max. $1.21 \mathrm{mg} / \mathrm{mL}$ ). Other flavonoids were below the LOQ. Mean sum of phenolic acids (SCA) was $2.14 \mathrm{mg} / \mathrm{mL}$; the highest concentration $(4.17 \mathrm{mg} / \mathrm{mL})$ was observed for PEX1.10, while the lowest for PEX1.6 (1.09 mg/mL). The richest in polyphenols (SPP) was product PEX1.3

Table 5. Content of determined polyphenolic compounds in PEX1 (mg/mL).

\begin{tabular}{|c|c|c|c|c|c|}
\hline & CA & RA & SCA & Lgr $=$ SF & SPP \\
\hline PEX1.1 & $0.28^{\mathrm{b}}$ & $2.06^{\mathrm{c}}$ & $2.34^{\mathrm{c}}$ & $0.45^{\mathrm{c}}$ & $2.78^{\mathrm{c}}$ \\
\hline PEX1.2 & $0.15^{\mathrm{b}}$ & $1.53^{\mathrm{b}}$ & $1.68^{\mathrm{b}}$ & $0.55^{\mathrm{b}}$ & $2.23^{\mathrm{b}}$ \\
\hline PEX1.3 & $0.21^{\mathrm{d}}$ & $3.18^{\mathrm{c}}$ & $3.39^{\mathrm{d}}$ & $1.21^{\mathrm{d}}$ & $4.60^{\mathrm{d}}$ \\
\hline PEX1.4 & $0.12^{\mathrm{d}}$ & $1.48^{\mathrm{c}}$ & $1.60^{\mathrm{c}}$ & $0.61^{\mathrm{c}}$ & $2.21^{\mathrm{c}}$ \\
\hline PEX1.5 & $0.10^{\mathrm{a}}$ & $1.03^{\mathrm{c}}$ & $1.13^{\mathrm{c}}$ & $0.61^{\mathrm{d}}$ & $1.74^{\mathrm{c}}$ \\
\hline PEX1.6 & $0.11^{\mathrm{a}}$ & $0.98^{\mathrm{c}}$ & $1.09^{\mathrm{c}}$ & $0.51^{\mathrm{a}}$ & $1.60^{\mathrm{c}}$ \\
\hline PEX1.7 & $0.12^{\mathrm{a}}$ & $1.09^{\mathrm{a}}$ & $1.21^{\mathrm{a}}$ & $0.57^{\mathrm{a}}$ & $1.77^{\mathrm{a}}$ \\
\hline PEX1.8 & $0.18^{\mathrm{b}}$ & $2.94^{\mathrm{b}}$ & $2.12^{\mathrm{b}}$ & $0.09^{\mathrm{b}}$ & $2.21^{\mathrm{b}}$ \\
\hline PEX1.9 & $0.17^{\mathrm{a}}$ & $2.47^{\mathrm{a}}$ & $2.64^{\mathrm{a}}$ & $0.19^{\mathrm{b}}$ & $2.83^{\mathrm{b}}$ \\
\hline PEX1.10 & $0.17^{\mathrm{a}}$ & $4.00^{\mathrm{a}}$ & $4.17^{\mathrm{a}}$ & $0.18^{\mathrm{a}}$ & $4.35^{\mathrm{a}}$ \\
\hline MEAN* & 0.16 & 1.98 & 2.14 & 0.50 & 2.63 \\
\hline MEDIAN & 0.16 & 1.74 & 1.90 & 0.53 & 2.22 \\
\hline MIN & 0.10 & 0.98 & 1.09 & 0.09 & 1.60 \\
\hline MAX & 0.28 & 4.00 & 4.17 & 1.21 & 4.60 \\
\hline SD* & 0.05 & 0.94 & 0.97 & 0.30 & 1.00 \\
\hline
\end{tabular}

Data are expressed as the mean; *, for the analyzed product population; $\mathrm{CV}:{ }^{\mathrm{a}}<1 \%,{ }^{\mathrm{b}}<3 \%,{ }^{\mathrm{c}}<5 \%,{ }^{\mathrm{d}}<7 \% ; \mathrm{n}=2 \times 3$; $\mathrm{CA}$, caffeic acid; RA, rosmarinic acid; SCA, sum of caffeic acid derivatives; Lgr, luteolin-7- $O$ - $\beta$-glucuronide; SF, sum of flavonoids; SPP, sum of polyphenols. 
(4.60 $\mathrm{mg} / \mathrm{mL})$, the poorest PEX1.6 $(1.60 \mathrm{mg} / \mathrm{mL})$; mean value was $2.63 \mathrm{mg} / \mathrm{mL}$. The concentrations of the most abundant compounds, rosmarinic acid, and luteolin-7- $O$ - $\beta$-glucuronide were included in the analysis of variance and post hoc comparisons. Obtained results showed significant differences between most of the analyzed batches. Data regarding PEX1 are presented in Table 5 and Figures 5a, 6a.

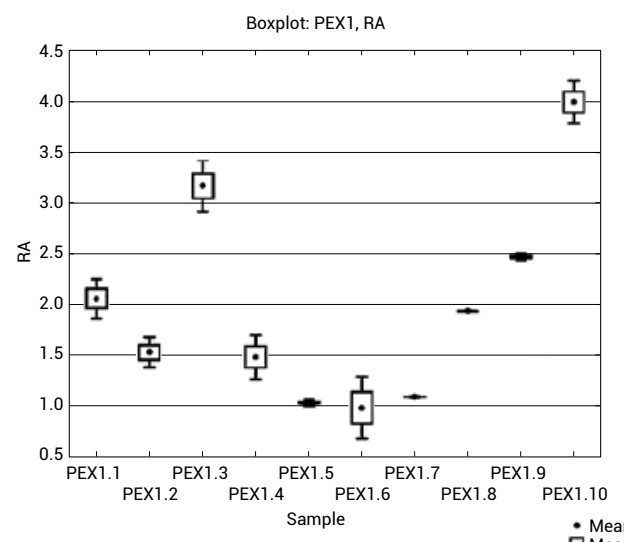

a) PEX1

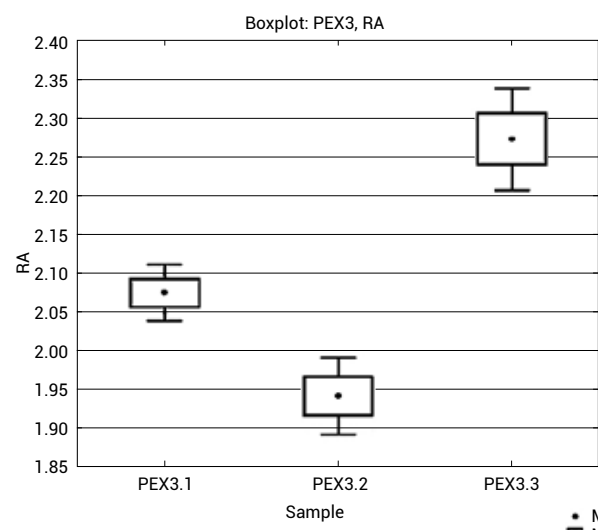

c) PEX3
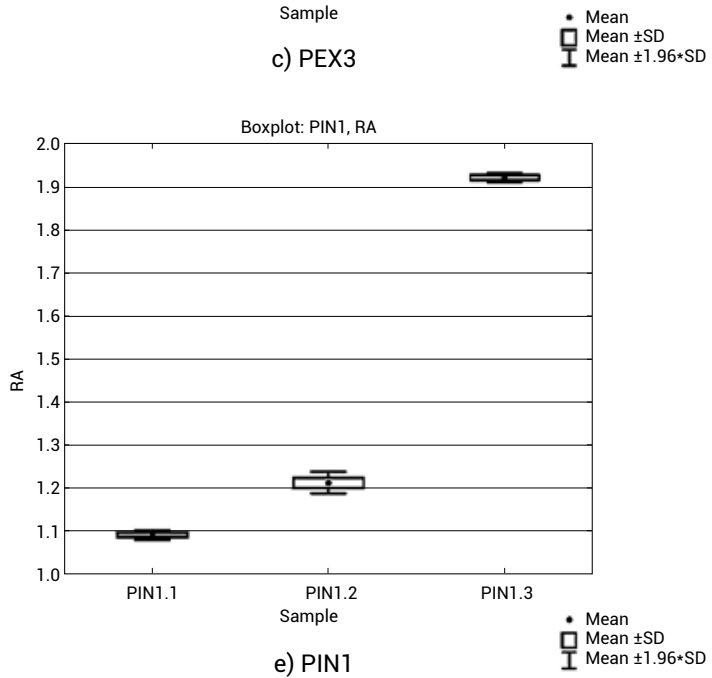

\section{Composition of PEX2}

The analysis of five PEX2 batches (PEX2.1PEX2.5) allowed us to determine the concentration of eight compounds. The mean rosmarinic acid content was $0.47 \mathrm{mg} / \mathrm{mL}$ (with min. value $0.05 \mathrm{mg} / \mathrm{mL}$ and max. value at $0.84 \mathrm{mg} / \mathrm{mL}$ ), chlorogenic acid mean concentration $0.15 \mathrm{mg} / \mathrm{mL}$ (min. $0.04 \mathrm{mg} / \mathrm{mL}$, $\max .0 .20 \mathrm{mg} / \mathrm{mL}$ ) and caffeic acid $-0.04 \mathrm{mg} / \mathrm{mL}$
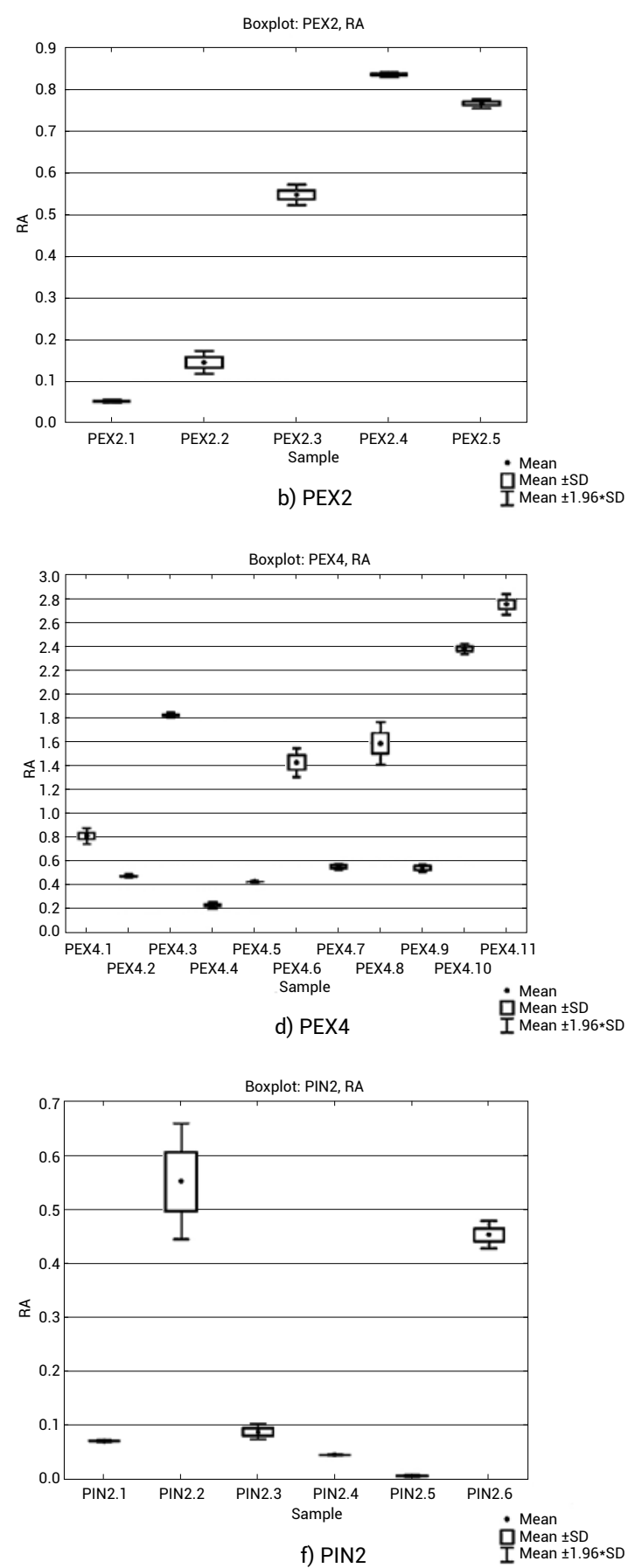

Figure 5. Boxplot of concentrations of rosmarinic acid in PEX1-4 and PIN1-2 samples. 


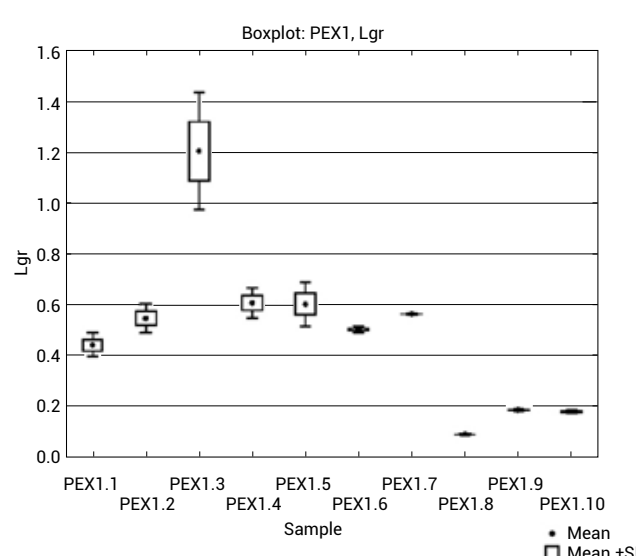

a) PEX1

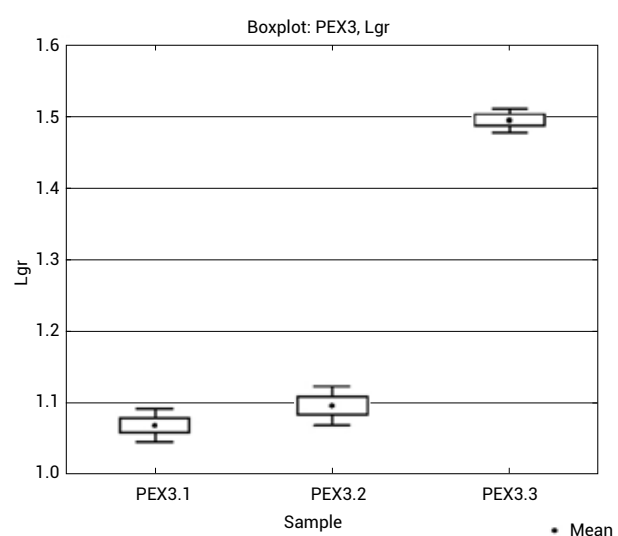

c) PEX3

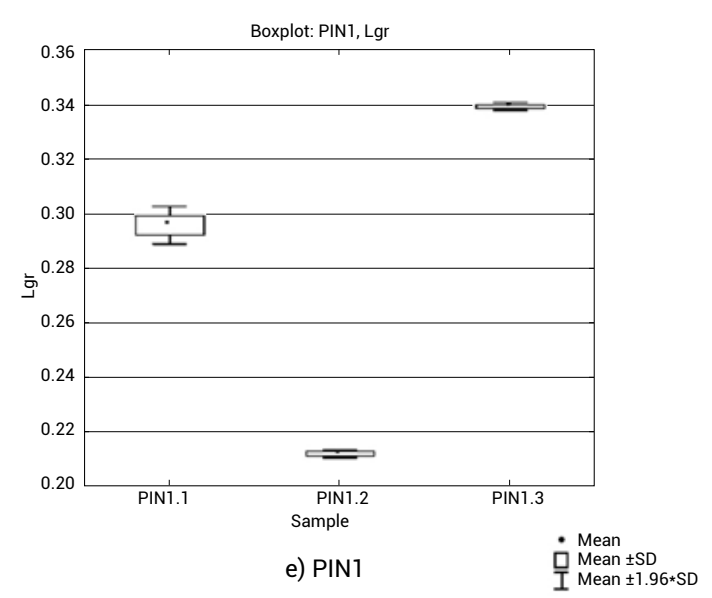

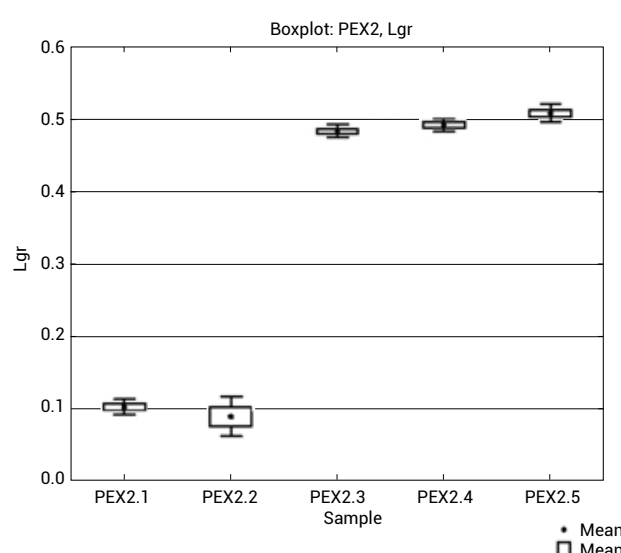

b) PEX2

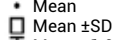

I Mean $\pm 1.96 * S D$

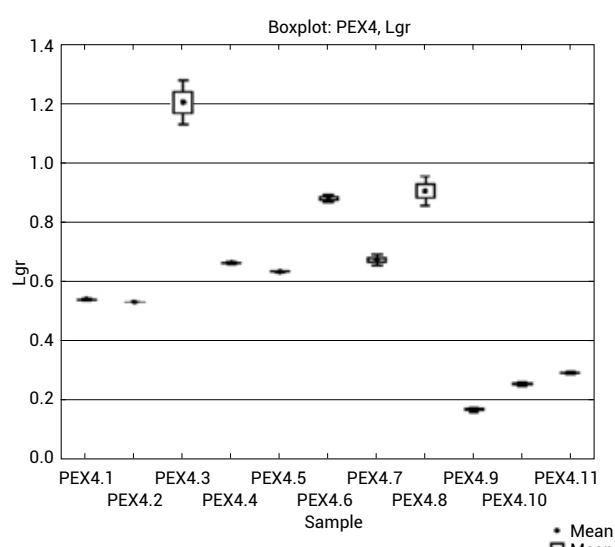

d) PEX4

$\dot{\text { Q Mean }}$ Mean $\pm S D$

I Mean $\pm 1.96 * S D$

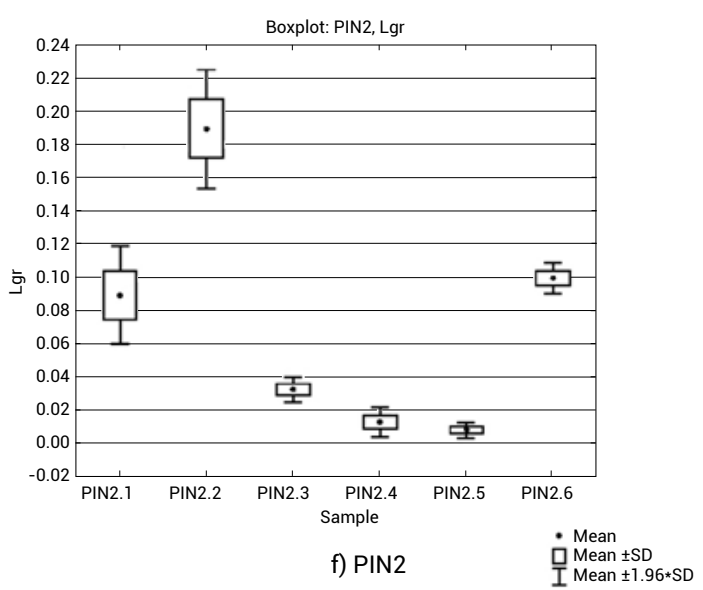

Figure 6. Boxplot of concentrations of luteolin-7-O- $\beta$-glucuronide in PEX1-4 and PIN1-2 samples.

(min. $0.03 \mathrm{mg} / \mathrm{mL}$, max. $0.05 \mathrm{mg} / \mathrm{mL}$ ). Mean sum of phenolic acids was $0.66 \mathrm{mg} / \mathrm{mL}$, max. SCA was observed in sample PEX2.4 $(1.08 \mathrm{mg} / \mathrm{mL})$. Among flavonoids, concentrations of five compounds were measured: eriocitrin $(0.59 \mathrm{mg} / \mathrm{mL}$, min. $0.10 \mathrm{mg} / \mathrm{mL}$, $\max .1 .42 \mathrm{mg} / \mathrm{mL}$ ), eriodictyol (0.14 mg/mL, min. $0.08 \mathrm{mg} / \mathrm{mL}$, max. $0.24 \mathrm{mg} / \mathrm{mL}$ ), luteolin-7- $O$ - $\beta$-glucuronide $(0.34 \mathrm{mg} / \mathrm{mL}, \min$. $0.09 \mathrm{mg} / \mathrm{mL}$, max. $0.51 \mathrm{mg} / \mathrm{mL})$, luteolin-7-Orutinoside $(0.29 \mathrm{mg} / \mathrm{mL}$, $\min$. $0.12 \mathrm{mg} / \mathrm{mL}$, max. $0.48 \mathrm{mg} / \mathrm{mL})$ and luteolin $(0.16 \mathrm{mg} / \mathrm{mL}$, $\mathrm{min}$. $0.09 \mathrm{mg} / \mathrm{mL}$ and max. $0.29 \mathrm{mg} / \mathrm{mL}$ ). Mean sum of flavonoids (SF) was $1.52 \mathrm{mg} / \mathrm{mL}$, the highest SF content $(2.77 \mathrm{mg} / \mathrm{mL})$ was observed in sample PEX2.3, 
the lowest $(0.66 \mathrm{mg} / \mathrm{mL})$ in PEX2.2. The richest in polyphenols (SPP) also was PEX2.3 $(3.57 \mathrm{mg} / \mathrm{mL})$ and the poorest PEX2.2. $(0.87 \mathrm{mg} / \mathrm{mL})$. ANOVA and Scheffé post hoc analysis revealed that the concentration of rosmarinic acid was statistically different for all analyzed batches; for luteolin-7$O$ - $\beta$-glucuronide significant differences were observed in most of them. Those data are presented in Table 6 and Figures 5b, 6 b.

\section{Composition of PEX3}

The concentration of six compounds - three caffeic acid derivatives and three flavonoids - were measured in three PEX3 (PEX3.1-PEX3.3) batches. Mean rosmarinic acid content was $2.10 \mathrm{mg} / \mathrm{mL}$ (with min. concentration at $1.94 \mathrm{mg} / \mathrm{mL}$ and max. at $2.27 \mathrm{mg} / \mathrm{mL}$ ), caffeic acid $0.08 \mathrm{mg} / \mathrm{mL}$ (min. $0.07 \mathrm{mg} / \mathrm{mL}$, max.
$0.08 \mathrm{mg} / \mathrm{mL}$ ), chlorogenic acid $0.30 \mathrm{mg} / \mathrm{mL}$ (min. at $0.28 \mathrm{mg} / \mathrm{mL}$ and $\max .0 .32 \mathrm{mg} / \mathrm{mL}$ ); eriocitrin $0.77 \mathrm{mg} / \mathrm{mL}$ (min. $0.56 \mathrm{mg} / \mathrm{mL}$, max. $1.19 \mathrm{mg} / \mathrm{mL}$ ), eriodictyol $0.10 \mathrm{mg} / \mathrm{mL}$ (min. $0.00 \mathrm{mg} / \mathrm{mL}$, $\max$. $0.16 \mathrm{mg} / \mathrm{mL}$ ), luteolin-7- $O$ - $\beta$-glucuronide $1.22 \mathrm{mg} / \mathrm{mL}$ (min. $1.07 \mathrm{mg} / \mathrm{mL}$, max. $1.50 \mathrm{mg} / \mathrm{mL}$ ), and luteolin7- $O$-rutinoside $0.38 \mathrm{mg} / \mathrm{mL}$ (min. $0.27 \mathrm{mg} / \mathrm{mL}$, max. $0.48 \mathrm{mg} / \mathrm{mL}$ ). Mean SCA was $2.47 \mathrm{mg} / \mathrm{mL}$, the highest content was observed in PEX3.3 (2.62 mg/mL), the lowest in PEX3.2 (2.35 mg/mL). Mean sum of flavonoids was $2.47 \mathrm{mg} / \mathrm{mL}$, while mean sum of polyphenols was $4.94 \mathrm{mg} / \mathrm{mL}$. Statistically significant differences in rosmarinic acid concentration were observed at all analyzed batches, while for luteolin7-O- $\beta$-glucuronide between two pairs of samples. Data regarding PEX3 are presented in Table 7 and Figures 5c, 6c.

Table 6. Content of determined polyphenolic compounds in PEX2 (mg/mL).

\begin{tabular}{|c|c|c|c|c|c|c|c|c|c|c|c|}
\hline & ChA & CA & RA & SCA & Er & E & Lgr & Lr & L & SF & SPP \\
\hline PEX2.1 & $0.10^{\mathrm{a}}$ & $0.05^{\mathrm{a}}$ & $0.05^{\mathrm{a}}$ & $0.20^{\mathrm{a}}$ & $0.10^{\mathrm{a}}$ & $0.15^{\mathrm{c}}$ & $0.10^{\mathrm{a}}$ & $0.17^{\mathrm{b}}$ & $0.29^{\mathrm{b}}$ & $0.82^{\mathrm{b}}$ & $1.02^{\mathrm{b}}$ \\
\hline PEX2.2 & $0.04^{\mathrm{a}}$ & $0.03^{\mathrm{a}}$ & $0.15^{\mathrm{c}}$ & $0.22^{\mathrm{b}}$ & $0.12^{\mathrm{c}}$ & $0.13^{\mathrm{a}}$ & $0.09^{\mathrm{c}}$ & $0.12^{\mathrm{d}}$ & $0.20^{\mathrm{c}}$ & $0.66^{\mathrm{c}}$ & $0.87^{\mathrm{c}}$ \\
\hline PEX2.3 & $0.20^{\mathrm{a}}$ & $0.05^{\mathrm{a}}$ & $0.55^{\mathrm{b}}$ & $0.80^{\mathrm{b}}$ & $1.42^{\mathrm{c}}$ & $0.24^{\mathrm{b}}$ & $0.48^{\mathrm{a}}$ & $0.48^{\mathrm{b}}$ & $0.14^{\mathrm{a}}$ & $2.77^{\mathrm{c}}$ & $3.57^{\mathrm{b}}$ \\
\hline PEX2.4 & $0.20^{\mathrm{a}}$ & $0.04^{\mathrm{a}}$ & $0.84^{\mathrm{a}}$ & $1.08^{\mathrm{a}}$ & $0.64^{\mathrm{a}}$ & $0.10^{\mathrm{a}}$ & $0.49^{\mathrm{a}}$ & $0.33^{\mathrm{c}}$ & $0.10^{\mathrm{a}}$ & $1.65^{\mathrm{a}}$ & $2.73^{\mathrm{a}}$ \\
\hline PEX2.5 & $0.20^{\mathrm{a}}$ & $0.04^{\mathrm{a}}$ & $0.77^{\mathrm{a}}$ & $1.00^{\mathrm{a}}$ & $0.65^{\mathrm{b}}$ & $0.08^{\mathrm{a}}$ & $0.51^{\mathrm{a}}$ & $0.35^{\mathrm{b}}$ & $0.09^{\mathrm{a}}$ & $1.69^{\mathrm{b}}$ & $2.69^{\mathrm{b}}$ \\
\hline MEAN $^{*}$ & 0.15 & 0.04 & 0.47 & 0.66 & 0.59 & 0.14 & 0.34 & 0.29 & 0.16 & 1.52 & 2.18 \\
\hline MEDIAN & 0.20 & 0.04 & 0.55 & 0.80 & 0.64 & 0.13 & 0.48 & 0.33 & 0.14 & 1.65 & 2.69 \\
\hline MIN & 0.04 & 0.03 & 0.05 & 0.20 & 0.10 & 0.08 & 0.09 & 0.12 & 0.09 & 0.66 & 0.87 \\
\hline MAX & 0.20 & 0.05 & 0.84 & 1.08 & 1.42 & 0.24 & 0.51 & 0.48 & 0.29 & 2.77 & 3.57 \\
\hline SD* & 0.07 & 0.01 & 0.32 & 0.38 & 0.48 & 0.06 & 0.20 & 0.13 & 0.07 & 0.75 & 1.05 \\
\hline
\end{tabular}

Data are expressed as the mean; *, for the analyzed product population; $\mathrm{CV}:{ }^{\mathrm{a}}<1 \%,{ }^{\mathrm{b}}<3 \%,{ }^{\mathrm{c}}<5 \%,{ }^{\mathrm{d}}<7 \% ; \mathrm{n}=2 \times 3$; ChA, chlorogenic acid; CA, caffeic acid; RA, rosmarinic acid; SCA, sum of caffeic acid derivatives; Er, eriocitrin; E, eriodictyol; Lgr, luteolin-7-O- $\beta$-glucuronide; Lr, luteolin-7-O-rutinoside; L, luteolin; SF, sum of flavonoids; SPP, sum of polyphenols.

Table 7. Content of determined polyphenolic compounds in PEX3 (mg/mL).

\begin{tabular}{|c|c|c|c|c|c|c|c|c|c|c|}
\hline & ChA & CA & RA & SCA & Er & E & Lgr & Lr & SF & SPP \\
\hline PEX3.1 & $0.29^{\mathrm{a}}$ & $0.08^{\mathrm{a}}$ & $2.07^{\mathrm{a}}$ & $2.45^{\mathrm{a}}$ & $1.19^{\mathrm{b}}$ & $0.13^{\mathrm{a}}$ & $1.07^{\mathrm{a}}$ & $0.48^{\mathrm{b}}$ & $2.88^{\mathrm{b}}$ & $5.33^{\mathrm{a}}$ \\
\hline PEX3.2 & $0.32^{\mathrm{a}}$ & $0.08^{\mathrm{a}}$ & $1.94^{\mathrm{a}}$ & $2.35^{\mathrm{a}}$ & $0.56^{\mathrm{a}}$ & $0.16^{\mathrm{a}}$ & $1.10^{\mathrm{b}}$ & $0.38^{\mathrm{a}}$ & $2.19^{\mathrm{a}}$ & $4.54^{\mathrm{a}}$ \\
\hline PEX3.3 & $0.28^{\mathrm{a}}$ & $0.07^{\mathrm{a}}$ & $2.27^{\mathrm{a}}$ & $2.62^{\mathrm{a}}$ & $0.56^{\mathrm{a}}$ & 0 & $1.50^{\mathrm{a}}$ & $0.27^{\mathrm{b}}$ & $2.32^{\mathrm{a}}$ & $4.94^{\mathrm{a}}$ \\
\hline MEAN $^{*}$ & 0.30 & 0.08 & 2.10 & 2.47 & 0.77 & 0.10 & 1.22 & 0.38 & 2.47 & 4.94 \\
\hline MEDIAN & 0.29 & 0.08 & 2.08 & 2.45 & 0.56 & 0.13 & 1.10 & 0.38 & 2.32 & 4.94 \\
\hline MIN & 0.28 & 0.07 & 1.94 & 2.35 & 0.56 & 0.00 & 1.07 & 0.27 & 2.19 & 4.54 \\
\hline MAX & 0.32 & 0.08 & 2.27 & 2.62 & 1.19 & 0.16 & 1.50 & 0.48 & 2.88 & 5.33 \\
\hline SD* & 0.02 & 0.01 & 0.14 & 0.11 & 0.30 & 0.07 & 0.19 & 0.09 & 0.30 & 0.32 \\
\hline
\end{tabular}

Data are expressed as the mean; *, for the analyzed product population; $\mathrm{CV}$ : ${ }^{\mathrm{a}}<1 \%,{ }^{\mathrm{b}}<3 \%,{ }^{\mathrm{c}}<5 \%,{ }^{\mathrm{d}}<7 \%$; $\mathrm{n}=2 \times 3$; ChA, chlorogenic acid; CA, caffeic acid; RA, rosmarinic acid; SCA, sum of caffeic acid derivatives; Er, eriocitrin; E, eriodictyol; Lgr, luteolin-7-O- $\beta$-glucuronide; Lr, luteolin-7- $O$-rutinoside; L, luteolin; SF, sum of flavonoids; SPP, sum of polyphenols. 
Table 8. Content of determined polyphenolic compounds in PEX4 (sage tincture) (mg/mL).

\begin{tabular}{|c|c|c|c|c|c|}
\hline & CA & RA & SCA & Lgr $=$ SF & SPP \\
\hline PEX4.1 & $0.03^{\mathrm{a}}$ & $0.82^{\mathrm{c}}$ & $0.85^{\mathrm{c}}$ & $0.54^{\mathrm{a}}$ & $1.39^{\mathrm{b}}$ \\
\hline PEX4.2 & $0.04^{\mathrm{a}}$ & $0.48^{\mathrm{a}}$ & $0.53^{\mathrm{a}}$ & $0.53^{\mathrm{a}}$ & $1.06^{\mathrm{a}}$ \\
\hline PEX4.3 & $0.08^{\mathrm{a}}$ & $1.83^{\mathrm{b}}$ & $1.92^{\mathrm{b}}$ & $1.21^{\mathrm{c}}$ & $3.12^{\mathrm{b}}$ \\
\hline PEX4.4 & $0.04^{\mathrm{a}}$ & $0.23^{\mathrm{c}}$ & $0.27^{\mathrm{b}}$ & $0.66^{\mathrm{a}}$ & $0.94^{\mathrm{b}}$ \\
\hline PEX4.5 & $0.05^{\mathrm{a}}$ & $0.43^{\mathrm{a}}$ & $0.48^{\mathrm{a}}$ & $0.63^{\mathrm{a}}$ & $1.11^{\mathrm{a}}$ \\
\hline PEX4.6 & $0.07^{\mathrm{d}}$ & $1.43^{\mathrm{c}}$ & $1.50^{\mathrm{d}}$ & $0.88^{\mathrm{b}}$ & $2.38^{\mathrm{c}}$ \\
\hline PEX4.7 & $0.05^{\mathrm{a}}$ & $0.56^{\mathrm{b}}$ & $0.61^{\mathrm{b}}$ & $0.67^{\mathrm{a}}$ & $1.28^{\mathrm{a}}$ \\
\hline PEX4.8 & $0.07^{\mathrm{a}}$ & $1.60^{\mathrm{c}}$ & $1.66^{\mathrm{c}}$ & $0.91^{\mathrm{d}}$ & $2.57^{\mathrm{c}}$ \\
\hline PEX4.9 & $0.08^{\mathrm{a}}$ & $0.55^{\mathrm{c}}$ & $0.63^{\mathrm{b}}$ & $0.17^{\mathrm{a}}$ & $0.79^{\mathrm{b}}$ \\
\hline PEX4.10 & $0.09^{\mathrm{a}}$ & $2.39^{\mathrm{a}}$ & $2.48^{\mathrm{a}}$ & $0.25^{\mathrm{a}}$ & $2.73^{\mathrm{a}}$ \\
\hline PEX4.11 & $0.09^{\mathrm{a}}$ & $2.76^{\mathrm{a}}$ & $2.84^{\mathrm{a}}$ & $0.29^{\mathrm{a}}$ & $3.14^{\mathrm{a}}$ \\
\hline MEAN* & 0.06 & 1.19 & 1.25 & 0.61 & 1.86 \\
\hline MEDIAN & 0.07 & 0.82 & 0.85 & 0.63 & 1.39 \\
\hline MIN & 0.03 & 0.23 & 0.27 & 0.17 & 0.79 \\
\hline MAX & 0.09 & 2.76 & 2.84 & 1.21 & 3.14 \\
\hline SD* & 0.02 & 0.82 & 0.84 & 0.30 & 0.88 \\
\hline
\end{tabular}

Data are expressed as the mean; *, for the analyzed product population; $\mathrm{CV}:{ }^{\mathrm{a}}<1 \%,{ }^{\mathrm{b}}<3 \%,{ }^{\mathrm{c}}<5 \%,{ }^{\mathrm{d}}<7 \% ; \mathrm{n}=2 \times 3$;

$\mathrm{CA}$, caffeic acid; RA, rosmarinic acid; SCA, sum of caffeic acid derivatives; Lgr, luteolin-7- $O$ - $\beta$-glucuronide; SF, sum of flavonoids; SPP, sum of polyphenols.

\section{Composition of PEX4 (sage tincture)}

We determined the concentration of three compounds (caffeic acid, rosmarinic acid, and luteolin-7-O- $\beta$-glucuronide) in eleven sage tincture batches (PEX4.1-PEX4.11). It was found that the most abundant compound was rosmarinic acid (mean $1.19 \mathrm{mg} / \mathrm{mL}$, concentrations varied from 0.23 to $2.76 \mathrm{mg} / \mathrm{mL}$ ), followed by luteolin-7-O- $\beta$ glucuronide (mean concentration $0.61 \mathrm{mg} / \mathrm{mL}$, values from 0.17 to $1.21 \mathrm{mg} / \mathrm{mL}$ ) and caffeic acid (mean $0.06 \mathrm{mg} / \mathrm{mL}$, values from 0.03 to $0.09 \mathrm{mg} / \mathrm{mL}$ ). The highest sum of polyphenols was observed in PEX4.11 (3.14 mg/mL) and PEX4.3 (3.12 mg/mL).
Product PEX4.11 also had the highest sum of phenolic acids $(2.84 \mathrm{mg} / \mathrm{mL})$. ANOVA and Scheffé post hoc analysis showed statistically significant differences in both rosmarinic acid and luteolin-7-O- $\beta$ glucuronide concentrations between most batches. Detailed numerical data are presented in Table 8, while the results of statistical analysis are presented in Figures 5d, 6d.

\section{Composition of PIN1}

Three PIN1 batches (PIN1.1- PIN1.3) were tested for concentration of caffeic acid (mean value $0.10 \mathrm{mg} / \mathrm{mL}$, $\min .0 .08 \mathrm{mg} / \mathrm{mL}$ and $\max$.

Table 9. Content of determined polyphenolic compounds in PIN1 (mg/mL).

\begin{tabular}{|c|c|c|c|c|c|}
\hline & $\mathrm{CA}$ & RA & SCA & $\mathrm{Lgr}=\mathrm{SF}$ & SPP \\
\hline PIN1.1 & $0.09^{\mathrm{a}}$ & $1.09^{\mathrm{a}}$ & $1.19^{\mathrm{a}}$ & $0.30^{\mathrm{a}}$ & $1.48^{\mathrm{a}}$ \\
\hline PIN1.2 & $0.11^{\mathrm{a}}$ & $1.22^{\mathrm{a}}$ & $1.32^{\mathrm{a}}$ & $0.22^{d}$ & $1.54^{\mathrm{a}}$ \\
\hline PIN1.3 & $0.08^{\mathrm{a}}$ & $1.93^{\mathrm{a}}$ & $2.01^{\mathrm{a}}$ & $0.34^{b}$ & $2.35^{\mathrm{a}}$ \\
\hline MEAN* & 0.10 & 1.41 & 1.51 & 0.29 & 1.79 \\
\hline MEDIAN & 0.09 & 1.22 & 1.32 & 0.30 & 1.54 \\
\hline MIN & 0.08 & 1.09 & 1.19 & 0.22 & 1.48 \\
\hline MAX & 0.11 & 1.93 & 2.01 & 0.34 & 2.35 \\
\hline $\mathrm{SD}^{*}$ & 0.01 & 0.37 & 0.36 & 0.05 & 0.40 \\
\hline
\end{tabular}

Data are expressed as the mean; *, for the analyzed product population; $\mathrm{CV}$ : ${ }^{\mathrm{a}}<1 \%,{ }^{\mathrm{b}}<3 \%,{ }^{\mathrm{c}}<5 \%$, ${ }^{\mathrm{d}}<7 \%$; $\mathrm{n}=2 \times 3$;

CA, caffeic acid; RA, rosmarinic acid; SCA, sum of caffeic acid derivatives; Lgr, luteolin-7-O- $\beta$-glucuronide; SF, sum of flavonoids; SPP, sum of polyphenols. 
Table 10. Content of determined polyphenolic compounds in PIN2 (thyme syrup) (mg/mL).

\begin{tabular}{|c|c|c|c|c|c|}
\hline & CA & RA & SCA & Lgr=SF & SPP \\
\hline PIN2.1 & $0.02^{\mathrm{a}}$ & $0.07^{\mathrm{a}}$ & $0.09^{\mathrm{a}}$ & $0.09^{\mathrm{d}}$ & $0.18^{\mathrm{c}}$ \\
\hline PIN2.2 & $0.08^{\mathrm{c}}$ & $0.55^{\mathrm{d}}$ & $0.63^{\mathrm{d}}$ & $0.19^{\mathrm{c}}$ & $0.82^{\mathrm{c}}$ \\
\hline PIN2.3 & $0.02^{\mathrm{a}}$ & $0.09^{\mathrm{a}}$ & $0.11^{\mathrm{a}}$ & $0.03^{\mathrm{a}}$ & $0.14^{\mathrm{a}}$ \\
\hline PIN2.4 & $0.03^{\mathrm{a}}$ & $0.05^{\mathrm{a}}$ & $0.08^{\mathrm{a}}$ & $0.01^{\mathrm{a}}$ & $0.09^{\mathrm{a}}$ \\
\hline PIN2.5 & $0.06^{\mathrm{a}}$ & $0.01^{\mathrm{a}}$ & $0.07^{\mathrm{a}}$ & $0.01^{\mathrm{a}}$ & $0.08^{\mathrm{a}}$ \\
\hline PIN2.6 & $0.03^{\mathrm{c}}$ & $0.46^{\mathrm{b}}$ & $0.49^{\mathrm{b}}$ & $0.10^{\mathrm{c}}$ & $0.59^{\mathrm{b}}$ \\
\hline MEAN* & 0.04 & 0.20 & 0.25 & 0.07 & 0.32 \\
\hline MEDIAN & 0.03 & 0.08 & 0.10 & 0.06 & 0.16 \\
\hline MIN & 0.02 & 0.01 & 0.07 & 0.01 & 0.08 \\
\hline MAX & 0.08 & 0.55 & 0.63 & 0.19 & 0.82 \\
\hline SD* & 0.02 & 0.22 & 0.23 & 0.06 & 0.28 \\
\hline
\end{tabular}

Data are expressed as the mean; *, for the analyzed product population; $\mathrm{CV}:{ }^{\mathrm{a}}<1 \%,{ }^{\mathrm{b}}<3 \%,{ }^{\mathrm{c}}<5 \%,{ }^{\mathrm{d}}<7 \%$; $\mathrm{n}=2 \mathrm{x}$; CA, caffeic acid; RA, rosmarinic acid; SCA, sum of caffeic acid derivatives; Lgr, luteolin-7-O- $\beta$-glucuronide; SF, sum of flavonoids; SPP, sum of polyphenols.

$0.11 \mathrm{mg} / \mathrm{mL}$ ), rosmarinic acid (mean $1.41 \mathrm{mg} / \mathrm{mL}$, min. $1.09 \mathrm{mg} / \mathrm{mL}$ and $\max .1 .93 \mathrm{mg} / \mathrm{mL}$ ), and luteolin-7-O- $\beta$-glucuronide (mean $0.29 \mathrm{mg} / \mathrm{mL}$, min. $0.22 \mathrm{mg} / \mathrm{mL}$, $\max$. $0.34 \mathrm{mg} / \mathrm{mL}$ ). Mean SCA was $1.51 \mathrm{mg} / \mathrm{mL}$, with the highest value found in PIN1.3 (2.01 mg/mL) and the lowest in PIN1.1 $(1.19 \mathrm{mg} / \mathrm{mL})$. Product PIN1.3 also had highest values of SPP $(2.35 \mathrm{mg} / \mathrm{mL})$, while the lowest were observed in PIN1.1 (1.48 mg/mL). The concentrations of both rosmarinic acid and luteolin-7-O- $\beta$ glucuronide significantly varied for all batches. Detailed PIN1 data are presented in Table 9 and Figures 5e, 6e.

\section{Composition of PIN2 (thyme syrup)}

Six different thyme syrups (PIN2.1-PIN2.6) were analyzed in this study. Concentrations of the following compounds were calculated: rosmarinic acid (mean $0.20 \mathrm{mg} / \mathrm{mL}$, values from $0.01 \mathrm{mg} / \mathrm{mL}$ to $0.55 \mathrm{mg} / \mathrm{mL}$ ), caffeic acid (mean $0.04 \mathrm{mg} / \mathrm{mL}$, values from $0.02 \mathrm{mg} / \mathrm{mL}$ to $0.08 \mathrm{mg} / \mathrm{mL}$ ), and luteolin-7- $O$ - $\beta$-glucuronide (mean $0.07 \mathrm{mg} / \mathrm{mL}$, values from $0.01 \mathrm{mg} / \mathrm{mL}$ to $0.19 \mathrm{mg} / \mathrm{mL}$ ). The richest in phenolic acids $(0.63 \mathrm{mg} / \mathrm{mL})$ and polyphenols $(0.82 \mathrm{mg} / \mathrm{mL})$ was product PIN2.2. Mean values for SCA and SPP were respectively $0.25 \mathrm{mg} / \mathrm{mL}$ and $0.32 \mathrm{mg} / \mathrm{mL}$. Intra-batch differences in concentrations of both rosmarinic acid and luteolin7-O- $\beta$-glucuronide were analyzed. The results from ANOVA and Scheffé's post hoc test showed that their content in PIN2.2 was significantly different compared to the other batches. Figures 5f, 6f and Table 10 presents the abovementioned data.

\section{DISCUSSION}

Thirty-eight products from different batches, representing six liquid herbal medicinal products (HMPs) based on sage and thyme preparations were subjected to quality testing. Due to the complex composition of the herbal medicines tested, hydroethanolic extracts of reference materials (sage leaf and thyme herb, DER 1:100) and selected single-herb products (sage tincture, thyme syrup) were subjected to preliminary $\mathrm{U}(\mathrm{H}) \mathrm{PLC}$-ESI-MS analysis. That allowed us to determine which herbal substance could be the source of the evaluated compounds. Tables 2-3 show the qualitative composition of these herbal preparations and medicinal products. U(H)PLCESI-MS analysis of commercially available HMPs confirmed the presence of the components detected in reference materials.

Numerous experimental works report sage and thyme extracts as a rich source of polyphenols with antioxidant, anti-inflammatory, and antiseptic activities. U(H)PLC-ESI-MS experiments performed in our study revealed a set of sixty-five compounds in sage preparations (Table 3) and fifty-seven compounds in thyme preparations (Table 3 ). Their identity was achieved based on chromatographic data, MS fragmentation patterns, and literature. Ten authentic standards and four polyphenols previously separated from other plant materials were used for identification.

Seven caffeic acid derivatives were found in sage preparations, among which rosmarinic acid (RA) was the predominant one (except PEX2). Other peaks (Table 3 ) were referred to as sagerinic acid 
and salvianolic acids A, K, L, or Y. Salvianolic acid $\mathrm{L}$ showed potent antioxidant activity in the DPPH test conducted by Lu and Foo (32). Salvianolic acid $\mathrm{Y}$ is a new caffeic acid derivative isolated from S. officinalis in 2015 by Gong and co-workers (33). This compound exhibited a protective effect against hydrogen peroxide induced cell lesions. Among sage flavonoids, luteolin and its derivatives, mainly luteolin-7- $O$ - $\beta$-glucuronide, predominated. These compounds have been attributed to antioxidant, antiinflammatory, antispasmodic, and neuroprotective activities (59). Compound 26, tentatively identified as luteolin-7- $O$-(6"- $O$-acetyl)- $\beta$-glucoside has been reported in $S$. officinalis for the first time. A group of methylated flavones including cirsimaritin, hispidulin, nepetin, or their isomers, previously described by researchers in different Salvia sp. plants, was also observed in this experiment. Additionally, thirteen compounds identified as phenolic diterpenes were found. The presence of carnosic acid, reported by other authors (3), was not confirmed in this study, most likely due to the low stability of this compound and its rapid autooxidation to carnosol, followed by degradation to rosmanol, epirosmanol, 7-methoxyrosmanol, and galdosol (8).

Similarly, the presence of phenolic acids, as well as flavonoids, was confirmed in thyme preparations. The dominating group was also caffeic acid esters, two of them - sagerinic acid or its isomer and ( $\alpha$-hydroxyhydroferuloylcaffeoyl)caffeoyl hexoside - were reported in thyme herb for the first time. The presence of rosmarinic acid and salvianolic acids A, B, K in Thymus sp. has been known for a very long time. The most important of these, rosmarinic acid, has been extensively studied for its comprehensive effects, especially in the course of inflammatory diseases such as lung diseases, asthma, allergic rhinitis, and dermatitis $(60,61)$. There are also reports of its antiviral, antimicrobial, and analgesic effects (62). RA is currently considered as a candidate therapeutic agent for the treatment of various inflammatory diseases via inhibition of the HMGB1 (high mobility group box 1) signaling pathway. HMGB1 protein is a crucial cytokine that mediates the response to infection, injury, and inflammation (63). Among twelve flavones detected, two luteolin derivatives have not been previously described in thyme: luteolin-7-O-(2"-apiosyl-acetyl)$\beta$-glucoside and luteolin-7-O-glucuronide-3'-Oglucoside. Four others were identified as methylated flavones - two cirsimaritin isomers and two cirsineol isomers (e.g., cirsineol and eupatorin). The activity of these flavones was previously investigated, and it is not limited to the antioxidant action but also includes antiproliferative and anti-replicative effects against the influenza virus $(64,65)$. A group of flavanone derivatives - eriodictyol, eriodictyol-7- $O$ $\beta$-glucoside, eriocitrin, and naringenin - were also observed on chromatograms of thyme preparations and products. According to Fecka and Turek (20), eriocitrin can reach concentrations up to $1.9 \mathrm{mg} / \mathrm{g}$ of dried thyme herb. Recent studies on this compound's action report its beneficial effect on colon inflammation (66). Besides components from the main chemical groups, representatives of other nonvolatile compounds such as catechin, 12-hydroxyjasmonic acid, monoterpene glucoside, and biphenyls were also observed.

The conducted quantitative analysis of sage and thyme-based HMPs led us to determine the content of eight representative constituents (Tables 5-10). Our results indicate that rosmarinic acid is the most abundant polyphenolic compound in all analyzed samples of herbal medicines, except PEX2. Its concentration was highly variable not only between different HMPs but even for different batches of the same product. According to the literature data, RA content in the sage leaf can be from 2.9 up to $38.4 \mathrm{mg} / \mathrm{g}$ of dried herbal substance, and in thyme herb from 4.2 to $35.3 \mathrm{mg} / \mathrm{g}(20,29,51)$. With such significant variation in the concentration of this compound in the herbal material analyzed and the lack of pharmacopoeial regulations regarding its minimum content, it is clear that HMPs containing sage and thyme preparations will significantly differ in the level of rosmarinic acid. Likewise, up to 10 -fold differences in RA content were found in batches of sage tincture (PEX4, 0.2-2.8 mg/mL) and product PEX1 (1-4 mg/mL), the latter being a combination of sage tincture and liquid thyme extract. The results for PIN1 and PEX3 were similar (within the range of 1-2 $\mathrm{mg} / \mathrm{mL}$ ), but were only obtained for a small number of product batches. The other HMPs had lower RA concentrations. However, the differences in its level were many times greater (e.g., for thyme syrup PIN2 by as much as 55 -fold, $0.01-0.55 \mathrm{mg} / \mathrm{mL}$ ). ANOVA with post-hoc Scheffé analysis confirmed large variability in RA concentrations between the same products with different batch numbers. For PIN1, PEX2, and PEX3 we showed that the differences in RA levels were statistically significant for all batches tested. Other phenolic acids, such as caffeic and chlorogenic acid, were present in tested product samples in lower concentrations.

The differences in rosmarinic acid content are well demonstrated by the results presented per single medicine dose recommended by the producer. The content of RA per oral single dose varied from 
$5.5 \mathrm{mg}$ to $9.7 \mathrm{mg}$ per dose for PIN1 (5 mL of liquid) and from $0.1 \mathrm{mg}$ to $5.5 \mathrm{mg}$ per dose for PIN2 (10 mL of thyme syrup). Regarding externally applied solutions, the concentrations of RA in products diluted according to the manufacturer's recommendations were in the range of $1-4 \mathrm{mg} / \mathrm{mL}$ for PEX1 (undiluted topical spray), about $0.3 \mathrm{mg} / \mathrm{mL}$ for PEX3 (15\% solution, $V / V), 0.01-0.14 \mathrm{mg} / \mathrm{mL}$ for PEX4 (5\% solution of sage tincture, $V / V)$, and below $0.02 \mathrm{mg} / \mathrm{mL}$ for PEX2 $(2.5 \%$ solution, V/V).

Luteolin-7- $O$ - $\beta$-glucuronide ( $\mathrm{Lgr}$ ) is the most abundant flavonoid, its concentration reaches up to $14.5 \mathrm{mg} / \mathrm{g}$ in thyme herb and $10.6 \mathrm{mg} / \mathrm{g}$ in sage leaf; for its aglycone, it is $0.6 \mathrm{mg} / \mathrm{g}$ and $0.06 \mathrm{mg} / \mathrm{g}$ respectively $(20,67,68)$. The Lgr content in HMPs tested also showed significant variation and ranged from values near 0 to $1.5 \mathrm{mg} / \mathrm{mL}$ of product. Engelbertz and co-workers (69) pointed out the consequences of the lack of minimum content requirements for flavone derivatives, claiming that standardization of thyme herb only on essential oil does not guarantee a good quality medicinal product. Similar conclusions were reached by Begrow and co-workers, who believe that standardization on thymol alone appears to be unjustified (70). The results obtained in the present study support this claim, as the luteolin-7-O$\beta$-glucuronide content varied significantly for most batches of thyme syrup (PIN2), and were from 0.1 to $1.9 \mathrm{mg} /$ dose $(10 \mathrm{~mL})$, as well as for all product samples of PIN1 - from 1.1 to $1.7 \mathrm{mg} /$ dose $(5 \mathrm{~mL})$. For topical products, the concentration of $\mathrm{Lgr}$ at the recommended dilutions ranged from 0.1 to $1.2 \mathrm{mg} / \mathrm{mL}$ for PEX1, approximately $0.2 \mathrm{mg} / \mathrm{mL}$ for PEX3 and below $0.06 \mathrm{mg} / \mathrm{mL}$ for sage tincture - PEX4. The level of this compound in a $2.5 \%$ solution of PEX2 was below $0.01 \mathrm{mg} / \mathrm{mL}$. Significant differences in $\mathrm{Lgr}$ concentrations were observed in most of the analyzed product samples.

Among eriodyctiol derivatives, only eriocitrin was present in noticeable concentrations in PEX3 (mean concentrations in $15 \%$ solution of $0.1 \mathrm{mg} /$ $\mathrm{mL}$ ). In this product, eriocitrin was derived not only from thyme but mainly from peppermint, which was listed in the formulation alongside other medicinal plants (Table 1). Taking into account the sum of polyphenols the highest differences in SPP were observed again for thyme syrup PIN2 (tenfold, 0.8 to $8.2 \mathrm{mg} / \mathrm{dose}$ ), smaller for PEX1 (threefold, 1.6 to $4.6 \mathrm{mg} / \mathrm{mL}$ ) and PIN1 (one and a half times, 7.4 to $11.7 \mathrm{mg} /$ dose).

The most common indications for use of sage and thyme preparations include inflammation of the mucous membranes of the upper respiratory tract and productive cough. Although essential oils have documented beneficial antiseptic, antiphlogistic and expectorant effects, one should not forget that phenolic acids and flavonoids are equally significant for inhibiting infection and the inflammatory process. Polyphenols possess anti-inflammatory properties due to their ability to scavenge reactive oxygen species and inhibit the activity of enzymes, including but not limited to cyclooxygenase (COX) and lipoxygenase (LOX), thereby reducing the synthesis of leukotrienes and other pro-inflammatory factors (71). Chrysargyris and co-workers (72) showed that the polyphenol content of sage was positively correlated with the ferric reducing antioxidant power (FRAP). Such a relationship was not observed in the context of essential oil. A subsequent study on different plants from the Thymus genus showed that the alcoholic extracts have higher antioxidant activity than essential oils (23). Studies on decoction, infusion, and hydroethanolic extract of thyme displayed that preparations with the highest concentration of polyphenolic compounds had the strongest activity against gram-positive and gram-negative bacteria (73). An analogous study with sage extracts proved their antifungal activity (13). Increasing scientific attention is focusing on the non-volatile fraction of sage and thyme and pointing to the need to standardize them due to their polyphenol content, as these substances are largely responsible for therapeutic properties $(69,74)$. For example, thyme extracts show antispasmodic activity, which is at least due to the synergistic action of volatile compounds and luteolin glycosides (69). Luteolin exhibits a potent antispasmodic effect by inhibition of phosphodiesterase (PDE) isozymes. It revealed non-selective inhibition of PDE1-5 with $\mathrm{IC}_{50}$ values in a range of $10-20 \mu \mathrm{M}(75)$. The potential use of luteolin as an inhibitor of pulmonary mast cellassociated inflammation, activated by coronavirus infection, was also proposed (76). In silico, in vitro, in vivo and clinical studies strongly suggest that the pharmacological mechanism of the antiinflammatory activity of luteolin is related to the regulation of transcription factors (77).

Herbal substances and preparations, due to the presence of a broad spectrum of components with therapeutic potential, are difficult materials to standardize according to quality assumptions. Most often, their pharmacological properties are the effect of several components or even groups of phytochemicals. So, the selection of a chemical marker is critical for both standardization and quality control processes. The ideal chemical markers are compounds with proven pharmacological efficacy, 
that contribute to the therapeutic action of herbal medicines. Since phenolic acids and flavonoids have a significant effect on the pharmacological activity of the sage and thyme preparations, therefore, their content should not be neglected, focusing only on the essential oil content.

\section{CONCLUSIONS}

A comparative analysis of the polyphenolic composition of six selected sage and thyme-based HMPs was performed using U(H)PLC-ESI-MS and HPLC-DAD. Rosmarinic acid was the major polyphenolic compound in all herbal medicines tested. The second significant component was luteolin-7-O$\beta$-glucuronide. Other non-volatile compounds were detected at much lower concentrations. ANOVA with Scheffé's post hoc test confirmed that RA and Lgr contents differed significantly between consecutive batches of the same medicinal product. Since the HMPs batches tested differed significantly in their polyphenol content, it should be concluded that their quality in the analyzed range was neither constant nor repeatable.

In the current quality control system, most herbs are standardized on a single component or group of related compounds, e.g., essential oil content or flavonoid content on a selected authentic standard (commercially available). For rosmarinic acid and salvianolic acid B, the European Pharmacopoeia provides an assay by liquid chromatography. Our results unambiguously indicate that the scope of pharmaceutical analysis of sage leaf and thyme herb, and also their preparations and medicinal products, should include several groups or components with therapeutic activity, such as essential oil, phenolic acids, and flavonoids. Therefore, the assessment of rosmarinic acid and luteolin-7- $O$ - $\beta$-glucuronide in sage leaves and thyme herb and their pharmaceutical preparations is proposed as an additional quality control parameter, especially because both of these compounds are available as commercial standards. However, further research is needed to determine the minimum standardization requirements in this range.

\section{Acknowledgment}

The study was funded by Wrocław Medical University, grant no. SUB.D110.21.101.

\section{Conflict of interest}

The authors declare no conflicts of interest.

\section{REFERENCES}

1. Kroes B.: J. Ethnopharmacol. 158, 449, (2019).

2. Council of Europe: European Pharmacopoeia, 10th ed. Council of Europe: Strasbourg, France, 2019.

3. Ghorbani A., Esmaeilizadeh M.: J. Tradit. Complement. Med. 7, 433 (2017).

4. Prasanth R., Ravi V., Varsha P., Satyam S.: Med. Aromat. Plants 3, 1000164 (2014).

5. Sharma Y., Fagan J., Schaefer J.: J. Pharmacogn. Phytochem. 8, 3139 (2019).

6. https://www.ema.europa.eu/en/documents/ herbal-monograph/final-european-unionherbal-monograph-salvia-officinalis-1-foliumrevision-1_en.pdf (accessed on 03.11.2020).

7. https:/www.ema.europa.eu/en/documents/ herbal-opinion/opinion-hmpc-europeanunion-herbal-monograph-salvia-officinalis1-folium-revision-1_en.pdf (accessed on 03.11.2020).

8. https:/www.ema.europa.eu/en/documents/ herbal-report/final-assessment-report-salviaofficinalis-1-folium-salvia-officinalis-1aetheroleum-revision-1_en.pdf (accessed on 03.11.2020).

9. Wang M., Li J., Rangarajan M., Shao Y., LaVoie E., et al.: J. Agric. Food Chem. 46, 4869 (1998).

10. Lu Y., Foo L.: Phytochemistry 59, 117 (2002).

11. Coss E., Kealey C., Brady D., Walsh P.: Eur. J. Integr. Med. 19, 80 (2018).

12. Karimzadeh S., Farahpour M.: Indian J. Exp. Biol. 55, 98 (2017).

13. Martins N., Barros L., Santos-Buelga C., Henriques M., Silva S., Ferreira I.: Food Chem. 170, 378 (2015).

14. Melo G., Fonseca J., Farinha T., Pinho R.D.M., Grespan R., et al.: J. Med. Plant Res. 6, 4934 (2012).

15. Mocan A., Babotă M., Pop A., Fizeșan I., Diuzheva A., et al.: Antioxidants 9, 480 (2020).

16. Pelkonen O., Abass K., Wiesner J.: Regul. Toxicol. Pharmacol. 65, 100 (2013).

17. Boutaoui N., Zaiter L., Benayache F., Benayache S., Carradori S., et al.: Molecules 23, 463 (2018).

18. Li X., He T., Wang X., Shen M., Yan X., et al.: Chem. Biodivers. 16, e1900254 (2019).

19. https://www.ema.europa.eu/en/documents/ herbal-monograph/final-community-herbalmonograph-thymus-vulgaris-l-thymus-zygis1-herba_en.pdf (accessed on 03.11.2020).

20. Fecka I., Turek S.: Food Chem. 108, 1039 (2008).

21. https://www.ema.europa.eu/en/documents/ herbal-report final-assessment-report-thymus- 
vulgaris-1-vulgaris-zygis-1-herba_en.pdf (accessed on 03.11.2020).

22. Chizzola R., Michitsch H., Franz C.: J. Agric. Food Chem. 56, 6897 (2008).

23. Salehi B., Abu-Darwish M.S., Tarawneh A.H., Cabral C., Gadetskaya A.V., et al.: Trends Food Sci. Technol. 85, 287 (2019).

24. Shaban N.S., Tohamy M.A., El-Banna H.A., Radi A.M., El-Gendy A.A., Owis A.I.: WJPPS 4, 1988 (2015).

25. https://www.ema.europa.eu/en/ich-q2r1-validation-analytical-procedures-textmethodology (accessed on 20.07.2021)

26. Bodalska A., Kowalczyk A., Włodarczyk M., Fecka I.: Molecules 25, 69 (2020).

27. Wang M., Shao Y., Li J., Zhu N., Rangarajan M., et al.: J. Nat. Prod. 62, 454 (1999).

28. Wang M., Kikuzaki H., Zhu N., Sang S., Nakatani N., Ho C.: J. Agric. Food Chem. 48, 235 (2000).

29. Lu Y., Foo L.Y.: Phytochemistry 51, 91 (1999).

30. Dent M., Kovačević D.B., Bosiljkov T., Dragović-Uzelac V.: Croat. Chem. Acta 90, 451 (2017).

31. Fotovvat M., Radjabian T., Saboora A.: Rec. Nat. Prod. 13, 37 (2017).

32. Lu Y., Foo L.Y.: Tetrahedron Lett. 42, 8223 (2001).

33. Gong J., Ju A., Zhou D., Li D., Zhou W., et al.: Molecules 20, 683 (2015).

34. Schnitzler P., Nolkemper S., Stintzing F., Reichling J.: Phytomedicine 15, 62 (2008).

35. Celano R., Piccinelli A., Pagano I., Roscigno G., Campone L., et al.: Food Res. Int. 99, 298 (2017).

36. Moharram F., Mahmoud I., Mahmoud M., Sabry S.: Nat. Prod. Commun. 1, 745 (2006).

37. Miura K., Kikuzaki H., Nakatani N.: J. Agric. Food Chem. 50, 1845 (2002).

38. Nikolova M.T., Grayer R.J., Genova E., Porter E.: Biochem. Syst. Ecol. 34, 360 (2006).

39. Kontogianni V.G., Tomic G., Nikolic I., Nerantzaki A.A., Sayyad N., et al.: Food Chem. 136, 120 (2013).

40. Pacifico S., Piccolella S., Lettieri A., Nocera P., Bollino F., Catauro M.: J. Funct. Foods 29, 1 (2007).

41. Sallam A., Mira A., Ashour A., Shimizu K.: Phytomedicine 23, 1005 (2016).

42. Santos-Gomes P.C., Seabra R.M., Andrade P.B., Fernandes-Ferreira M.: J. Plant Sci. 162, 981 (2002).

43. Tada M., Hara T., Hara C., Kazuhiro C.: Phytochemistry 45, 1475 (1997).
44. Ivanović J., Djilas S., Jadranin M., Vajs V., Petrović N., et al.: J. Serbian Chem. Soc. 74, 717 (2009).

45. Wang M., Kikuzaki H., Lin C.C., Kahyaoglu A., Huang M.T., et al.: J. Agric. Food Chem. 47, 1911 (1999).

46. Hohmann J., Redei D., Mathe I., Blunden G.: Biochem. Syst. Ecol. 31, 427 (2003).

47. Pereira E., Barros L., Antonio A.L., Cabo Verde S., Santos-Buelga C., Ferreira I.: LWT 74, 34 (2016).

48. Nagy T., Solar S., Sontag G., Koenig J.: Food Chem. 128, 530 (2011).

49. Ziani B.E.C., Barros L., Boumehira A.Z., Bachari K., Heleno S.A., et al.: Food Funct. 9, 149 (2018).

50. Righi N., Boumerfeg S., Fernandes P.A.R., Deghima A., Baali F., et al.: Food Res. Int. 136, 109500 (2020).

51. Pereira E., Pimenta A., Barros L., Calhelha R., Antonio A., et al.: Food Funct. 9, 5150 (2018).

52. Silva A., Martins-Gomes C., Souto E.B., Schäfer J., Santos J.A., et al.: Antioxidants 9, 482 (2020).

53. Martins-Gomes C., Taghouti M., Schäfer J., Bunzel M., Silva A.M., Nunes F.M.: J. Funct. Foods 43, 154 (2018).

54. Galasso S., Pacifico S., Kretschmer N., Pan S., Marciano S., et al.: Phytochemistry 107, 80 (2014).

55. Vergara-Salinas J., Pérez-Jiménez J., Torres J.A.E., Pérez-Correa J.: J. Agric. Food Chem. 60, 10920 (2012).

56. Desta K.T., Kim G.S., El-Aty A.M.A., Raha S., Kim M.B., et al.: J. Chromatogr. B 1053, 1 (2017).

57. Simonyan A.V., Shinkarenko A.L., Litvienko V.I.: Rasti. Resur. 9, 395 (1973).

58. Hossain M.B., Rai D.K., Brunton N.P., MartinDiana A.B., Barry-Ryan C.: J. Agric. Food Chem. 58, 10576 (2010).

59. Kitajima J., Ishikawa T., Urabe A.: Chem. Pharm. Bull. 52, 1013 (2004).

60. Takeuchi H., Lu Z., Fujita T.: Biosci. Biotechnol. Biochem. 68, 1131 (2004).

61. Miura K., Inagaki T., Nakatani N.: Agr. Biol. Chem. 37, 1375 (1989).

62. Gašić U., Natić M., Mišić D., Lušić D., Milojković-Opsenica D., et al.: J. Food Comp. Anal. 44, 128 (2015).

63. Manzoor M., Ahmad N., Ahmed Z., Siddique R., Zeng X.-A., et al.: J. Food Biochem. 43, e12974 (2019).

64. Luo C., Zou L., Sun H., Peng J., Gao C., et al.: Front. Pharmacol. 11, 1 (2020). 
65. Amoah S.K., Sandjo L.P., Kratz J.M., Biavatti M.W.: Planta Med. 82, 388 (2016).

66. Nadeem M., Imran M., Aslam Gondal T., Imran A., Shahbaz M., et al.: Appl. Sci. 9, 3139 (2019).

67. Yang E.J., Ku S.K., Lee W., Lee S., Lee T., et al.: J. Cell. Physiol. 228, 975 (2013).

68. Sheng X., Sun Y., Yin Y., Chen T., Xu Q.: J. Pharm. Pharmacol. 60, 1523 (2008).

69. Yan H., Wang H., Ma L., Ma X., Yin J., et al.: Virol. J. 15, 88 (2018).

70. Guo G., Shi W., Shi F., Gong W., Li F., et al.: J. Biochem. Mol. Toxicol. 33, e22400 (2019).

71. Pereira O.R., Cardoso S.M.: Curr. Anal. Chem. 9, 382 (2013).

72. Farhat M., Chaouch-Hamada R., Sotomayor J., Landoulsi A.: Ind. Crops Prod. 54, 78 (2014).

73. Engelbertz J., Lechtenberg M., Studt L., Hensel A., Verspohl A.: J. Ethnopharmacol. 141, 848 (2012).
74. Begrow F., Engelbertz J., Feistel B., Lehnfeld R., Bauer K., Verspohl E.: Planta Med. 76, 311 (2010).

75. Agrawal A.: Int. J. Pharm. Sci. Nanotechnol. 4, 1394 (2011).

76. Chrysargyris A., Mikallou M., Petropoulos S., Tzortzakis N.: Agronomy 10, 727 (2020).

77. Martins N., Barros L., Santos-Buelga C., Silva S., Henriques M., Ferreira I.: Food Chem. 167, 131 (2014).

78. Walch S.G., Tinzoh L.N., Zimmermann B.F., Stühlinger W., Lachenmeier D.: Front. Pharmacol. 2, 1 (2011).

79. Ko W.C., Shih C.M., Lai Y.H., Chen J.H., Huang H.L.: Biochem. Pharmacol. 68, 2087 (2004).

80. Theoharides T.C.: Biofactors 46, 306 (2020).

81. Aziz N., Kim M.-Y., Cho J.: J. Ethnopharmacol. 225, 342 (2018). 